\title{
EFFECT OF ELEVATED TEMPERATURES ON CELL CYCLE KINETICS OF RAT GLIOSARCOMA CELLS
}

Pepi Ross-Riveros

(Ph.D. thesis)

July 1978

Prepared for the U. S. Department of Energy under Contract $W-7405-E N G-48$

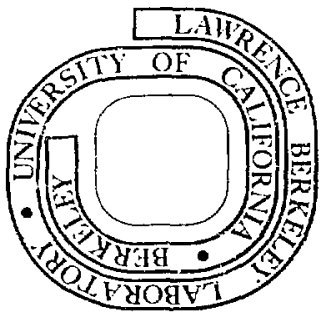


EFFECT OF ELEVATED TEMPERATURES ON CELL CYCLE KINETICS OF RAT GLIOSARCOMA CELLS

July 1978

\author{
Pepi Ross-Riveros \\ University of California \\ Lawrence Berkeley Laboratory \\ Berkeley, California
}


EFFECT OF ELEVATED TEMPERATURES ON CELL CYCLE

KINETICS OF RAT SLIOSARCOMA CELLS

\section{Contents}

Abstract . . . . . . . . . . . . . . . . . . v

Introduction . . . . . . . . . . . . . . . . . . . . 1

I. Background Literature . . . . . . . . . . . . . . 1

A. Clinical Motivation . . . . . . . . . . . . 1

B. Cell and Tissue ................ . 2

1. Relative Sensitivity of Normal and Tumor Cells. 3

2. Oxyger Effects............... . . . . 5

3. Synergistic Interaction .......... 5

4. Mode of Injury and Repair . . . . . . . . 8

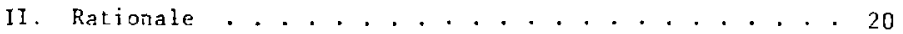

Materials and Methods . . . . . . . . . . . . . . . 23

I. Hyperthermic Treatment . . . . . . . . . . . . 24

II. Thermal Dosimetry . . . . . . . . . . . . . . 26

III. Flow Micrsfluorometry . . . . . . . . . . . . 27

IV. Autoridiography . . . . . . . . . . . 30

A. Labeling Index (LI) ............ 30

B. Percent Labeled Mitoses (PLM) . . . . . . . 30

Results ... . . . . . . . . . . . . . . . . 32

I. Survival Curves . . . . . . . . . . . . . . . 32

II. Supernatant Cells . . . . . . . . . . . . . . 33

III. Dye Exclusion Measurements . . . . . . . . . . . 34

IV. Double Hyperti.armic Exposure . . . . . . . . . . . 35 
v. Kinetic Studies.................. . . 36

A. Flow Microfluorometry . . . . . . . . . . 36

B. Autoradiographic Studies with DNA Labels . . . . 40

1. Labeling Indax ............... . 40

2. Pulse Labeled Mitoses............. 41

Discussion . . . . . . . . . . . . . . . . . . 42

I. Survival Data... . . . . . . . . . 42

II. Kinetics................. . . . 48

Acknowledgments . . . . . . . . . . . . . . . . . . 55

References . . . . . . . . . . . . . . . . . . . 56

jable . . . . . . . . . . . . . . . . . . . . 71

Figures . . . . . . . . . . . . . . . . . . . . . 72 


\section{EFFECT OF ELEVATED TEMPERATUPES ON CELL CYCLE KINETICS OF RAT GLIOSARCOMA CELLS}

\section{Pepi Ross-Riveros}

Piology and Medicine Division, Lawrence Berkeley Laboratory, and Iniversity of California, Berkeley, California 94720

\section{ABSTRACT}

9L tat gliosarcoma cells were cxamined in vitro for survival response to hyperthermic temperatures ranging from $39.0^{\circ}$ to $45.0^{\circ} \mathrm{C}$ for graded exposure times. At $43.0^{\circ} \mathrm{C}$, the spit exposure response was also studied. The ability of a single cell to form a colrny or to exclute trypan blue viability stain was used as an endpoint for survival.

Changes in cell cycle kinetics resulting frcm hyperthermia were compared for iscsurvival levels achieved by appropriate exposure time to cither $42.5^{\circ} \mathrm{C}$ or $43.0^{\circ} \mathrm{C}$. After heat treatrent, celis were held at $37.0^{\circ} \mathrm{C}$ far varying recovery periods. Cells were then either prepared for flow microfluorometry (FMF), or exposed to tritiated thymidine ( 3 HTdR) and prepered for autoradiography.

The survival studies indicated that the rate of change in cell killing for each increasing degrce centigrade was greacer for temperaturcs below $43.0^{\circ} \mathrm{C}$ than for temperatures above $43.0^{\circ} \mathrm{C}$. An Arrhenius plot of the mortality rate us. the inverse of the absolute temperature reveals inactivation energies of $509 \mathrm{kcal}$ for temperatures be $1 \mathrm{ow}^{-4} 4.0^{\circ} \mathrm{C}$ and $109 \mathrm{kcal}$ for temperatures above $43.00 \mathrm{C}$. The shoulder width of the survival curves is maximal at $42.5^{\circ} \mathrm{C}$. Although no specific biological function has yet been associated with the shoulder region of a hyperthermic survival curve, the shou'der width does represent an important parametrr 
since it describes a threshold time after which significant cell killing occurs. Thus both $43.0^{\circ} \mathrm{C}$, the temperature at which mortality kinetics change, and $42.50 \mathrm{C}$, the temperature $a t$ which the shoulder width is maximum, represcnt critical temperatures for the $9 \mathrm{~L}$ cells.

Cells remained attached to the growing surface of the $t$ issue culture Elask throughout the treatment time necessary to estab]ish survival curves. However, prolonged treatment at cemperatures of 43. $0^{\circ} \mathrm{C}$ and higher causes cells to detach during treatment at a rate which curresponds to percent mortality as indicated by a trypan b] ue vita] stain.

When 9L cells are given an initial conditioning exposure to $4: 3.0 \% \mathrm{C}$, then returned to $37^{\circ} \mathrm{C}$ for 3 hours, followed by graded exposura intervis at $43.0^{\circ}$, the resulting survival curve indicates that cells regire longer time for equal cell killing than for the single exposure condition, suggesting that the ce? is possess a capability to adapt to the higher temperature. In the exponential region, as the initial exposure is increased (resulting in lower surviving fraction) the thermal tolerance increases. For initial exposures rerulting in survivals of $25 \%, 5 \%$, and $1 \%$, the thermal tolerance ratio was $2.3,3.3$, and 3.8 respectively. These values match those reported b; other researcher: using various cell lines for equivalent intitial survival levels.

Kinetic response using FMF, autoradiographic measures of labeling index (LI) and pulse labeled mitases (PLM), and population growth parameters all indicated that cells experience two types of blocks in cell progression through the cell cycle immediately following hyperthemic treatment. First of all, cells appear to be blocked wherever they 
may be in the cell cycle, resulting in a period of time which we have termed a period of "general arrest". Second, there appears to be a block in $S$ which lasts longer than the general arrest. Thus when cells are released from the general arrest, they progress through the cell cycle only so far as the $S$ block, resulting in a cohort of synchronized cells. The length of the general arrest is a function of both survival level and exposure temperature and is most prolonged for the Iongest exposure at the highest temperature. For example, when cells were treated to $25 \%$ survival using $43.00 \mathrm{C}$, cell numbers remained constant up to 29 hours after treatment. When cells were treated to the same survival using $42.5^{\circ} \mathrm{C}$, the number of cells began to incrcase at asout 18 hours post treatment and had nearly doubied at 30 hours post treatment. However, cells created to $2.5 \%$ survival using $42.50 \mathrm{C}$ did not increase their numbers until more than 21 hours post treatment and had only increased by a factor of 0.2 by 30 hours post treatment.

FMF analysis indicates that the general arrest occurs at all survival levels. Again, the general arrest increases as survival decreases or as cemperature increases. For example, at $43.0^{\circ}$, delays of 9,18 , and 24 hours are seen for survival levels of $75 \%, 25 \%$, and $2.5 \%$ respectively. In contrast, if $2.5 \%$ survival is achieved using $42.5^{\circ} \mathrm{C}$ the delay shortens to 9 hours. The delay is followed by an accumulation of cells with DNA content corresponding to S phase cells. These cells then progress through the cell cycle in a cohort.

An autoradiographic measure of the post treatment labeling inder (LI) suggests that incorporation of tritiated thymidine is suppressed 
below control levels during the period of general arrest. Following the general arrest, kinetic rates appear to increase and the incorporation of ${ }^{3} \mathrm{HTdR}$ then rises above control levels. The general arrest as measured by LI follows, with one excoption, the same pattern established by the cell count and FMF rechniques. That is, at $43.0^{\circ} \mathrm{C}$, the duration of the general arrest increases with decreasing survival level and Cor iso-survival Jevels the general arrest increases with increasing tempersture. At $42.5^{\circ} \mathrm{C}$, the length of the general arrest appared constant. for the three survival levels measured. This may have been due to a variation in the general arrest which was smaller than the three hour intervals at which samples were taker.

After heat treatment at $43.0^{\circ} \mathrm{C}$, pulse labelod mitoses (PLM) curves exhibit a lengthened G2+M phase in the initial portion of the curve. Then cells are treated to $75 \%$ survival level, $G 2+M$ is 3 times as long as for control cells. When treated to $2.5 \%$ survival level, the PiM curve shows that $G 2+M$ inc eases to 5 times the length of the control value. For $75 \%$ survival the lengthening of $G 2+M$ corresponds to the length of the gencral arrest indicated by previously mentioned techniques. And the trend of increasing length of general arrest with decreasing survival also appears to be preserved in the PLM data. The decrease in labeling index during thr: general arrest, followed by the FMF indication of an acumulation of cells in $S$, indicates that during the general arrest, cells are blocked in $S$. 


\section{INTRODUCTION}

\section{I . BACIKGROUND LITFRATURE}

Hyperthermia is under investigation at many laboratories both because of the clinical potential for using elevated temperatures in cancer therapy and because certain aspects about hasic cell physiology might be learned from observations on cell and organ systrms at elevated temperatures. Hyperthermia, as used in this thesis, refers to temperature statos in cells or animals which are above the physiological temperatures normally existing under homeothermic conirol of the animal involved.

\section{A. CLINICAL MOTIVATION}

Anecdotal cases of partial and complete tumor regression following the high fever that results from infectious discase forms part of the hasis for current clinical interest in hyerthermia as a treatmont modality for cancer. The history of clinical observatinns on the effect of high fever or locally applied heat on tumors has becu revicwed recently by Moricca et al., (1) and others. $(2,3,4)$

The first significant clinical report on the effects of hyporthermia on tumors was made by Buscín ${ }^{(5)}$ in 1866. Rohdenburg fiscovered. upon reviewing case histories in 1918 , that approximately half the recorded spontaneous tumor regressions were associated with high fevers, heat applications, or severe infections. (6) Artifically induced fever $\left(41.5^{\circ} \mathrm{C}\right.$ to $42.0^{\circ} \mathrm{C}$ for periode or several hours) was reported by Warren. in $1935^{(7)}$ and by Pettigrew in $1975^{(8,9)}$ to induce tumor regression. Also, Cavaliere $(10,11)$ has demonstrated partial and total regression of primary melanomas by regional perfusion with prewarmed blood of 
tutmors nccurring in 1 imbs of cancr patients. The tumors were raised to $41.50 \mathrm{C}$ to $43.50^{\circ} \mathrm{C}$ for several hours.

B. CFILL AND TISSUE

In parallel development with the clinical observations noted above, in vive and in vitro laboratory work his supplied some scientific has: is to support the clinical findings. The reader is reforred to whromes $1,2,12-24$ far recent reviews on cellular and tumor thermobiology. Gisvanella(I3) and Moricea(I) give special attention to the historical development of hyperthermia research.

There ate a fow findings which form a frariows for gany of the prosent investigations in hyporthermia. They will be briefly stated her tollowed by more detaigod riscussion. The first is that tumer colls

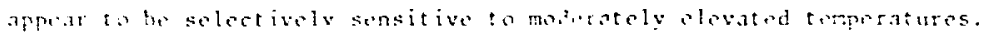
That is, supranormal tomperatures nay damage tumot calls more than the

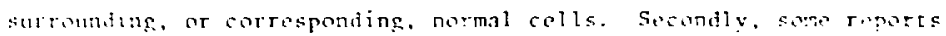

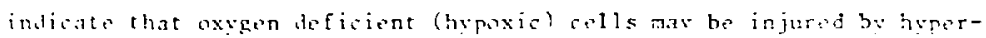
thermia as reabily as are exvenated eells. The inportance of these

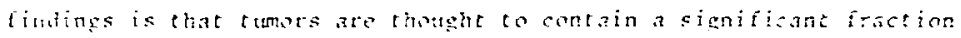

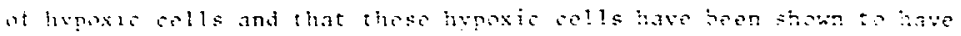

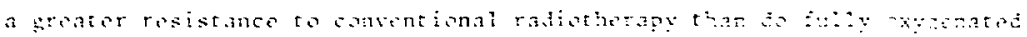

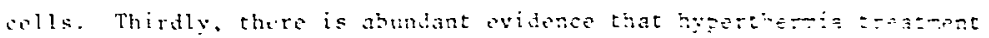

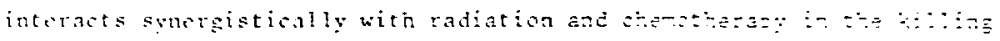

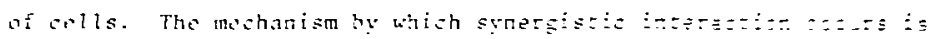

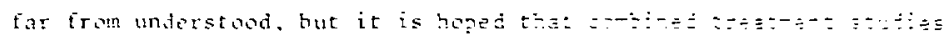

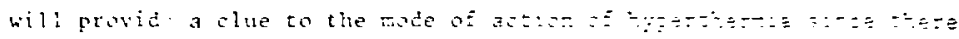

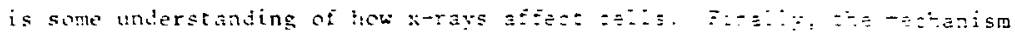


by which hyperthermia kills or injures cells and the manrer in which the injured cells repair and recover from this damage, may be quite different from that for other modes of injury. For instance, surviving cells once treated with hyperthermia are more resistant to killing by subsequent treatments. And kinetic studies have been roported which show that hyperthermic treatment induces delays, jlocks, ant s:-trronous. subpopulations in the treated cells which are qualitatively riffurent from blocks and delays induced by $x$-rays. In the following sections eacb of the abnve mertioned findings will be discussed in more deiail. 1. Relative Sensitivity of Normal ano Tumor Cells

One of the earliest cell culture studies thich exatiand the rolative sonsi:ivity of normal and malignant cells io heat wasts conuctuct by tambrert in 1912 (30) He found that mouse and rat sareoma colls we

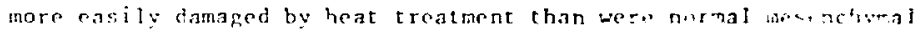
cells. Damage was measured by tae cell's ability to misrato tron an explant of tissue tbat was grown in a piacma ciot. In $: 349$. inn and Heidelberger ${ }^{(25)}$ discovered that cherically trastorroi cili folls werc killed more quickly at $43^{\circ} \mathrm{C}$ and $44^{\circ} \mathrm{C}$ than normal calls, ais ingh at $45^{\circ} \mathrm{C}$ the cells were equally sensitive.

Overfaard and Overgaatd $(21,31,32)$ noticed ulerastructurat ibers in tumor cells of mouse mamery carcinomas treated with hiperthermia, while interspersed stroma and vaseular cells in tha she : :nur fire not visibly altered.

Noting that the $\mathrm{pH}$ of interstitial fluid in human and rnime tumors is 0.3 to 0.5 units lower than the normal tissue $:-1$ of ahout 7.4 , Gerwick ${ }^{(33,34)}$ postulated, and demonstrat.3 in vitro, that the 
acid environment could potentiate hyperthermic damage in the tumor area resulting in increased tumor sensitivity. However, it has been demnnstrated that even when $\mathrm{pH}$ is carefully maintained at 7.4 , malignant cells are more thermosensitive than normal cells. Oxygen uptake of Novikoff hepatoma and Ehrlich ascites carcinoma cells was found to be suppressed at $42^{\circ} \mathrm{C}$, relative to $38^{\circ} \mathrm{C}$, while it remained unchanged for normal and regenerating liver cells. (11,36) Giovarella's (35) comparison of the suivival of normal embyonal mouse tissues and transformed, neoplastic mesenchymal cells after $43^{\circ} \mathrm{C}$ heat treatments in tissue culture". . indicate that the acquisition of biological malignant potential, both in vivo and in vitro, is accompanied by increased thermosensitivity." This finding was observed even when comparing a tumor-producing cell subline with the normal line from which it was derived.

Looking for the biochemical cause of this differential sensitivity of malignant cells, Mondovi et al. $(37,38,39)$ found that temperatures of $43^{\circ} \mathrm{C}$ were accompanied by reduced incorporation of labeled precursers into DNA, RNA, and protein of Novikoff and Morris 5123 hrpatoma cel $1 \mathrm{~s}$ whereas in regenerating 1 iver cells these same appeared unaffected. The same authors also found that lysosomes were more labile in hepatoma cells than in normal or regenerating liver cells.

There has been at least one case where cells transformed in vitre by polyoma virus or SV 40 virus, and assayed in vitro did not indicate a difierential sensitivity to heat. (40) Sensitivity was measured by monitoring growth curves of treated cells. However, if the transformed 
cells were used to produce in vivo tumors, the celis derived from these tumors did display differential sensitivity.

\section{Oxygen Effects}

There are at least two important aspects of the "oxygen effect" in hvperthermia treatment of tumor cells. The first is that hyperthermia kills hygoxic cells as successfully as euoxic (normally oxygonated) cells. $(21,41-44,47)$ The second aspect is that some evidence suggests that heat may sensitize hypoxic cells to $x$-irradiation more than it sensitizes euoxic cells. $(45,46)$ This is in contrast to the fact that ionizing radiation alone does not datoge hypoxic cells as much as it damages ruoxic cells. Some research indicates that oxic and euoxic cells are equally sensitive to elevated temperatures, $(41,48)$ but that tne allered $\mathrm{pH}^{(21,34)}$ and/or nutitional deficiencies ${ }^{(28)}$ which are often associated with hypoxic tumor cells cause further sensitization. Howover, it remains that hyperthermia may be especially useful in treating the hypoxic fraction of tumor cells which escape normal $x-$ ray troatment.

\section{Synergistic lnteractions}

Synorgism is observed when cells are treateri vith drugs while undergoing hyperthermic treatment $(29,49)$ and when hyperthermic troatment is combined with radiation. $(2,19,22,24,26,27,45,49-51)$

The cxtent of interaction depends on the position of cells in the cell cycle, $(27,51,52,58)$ oxygen concentration, (43) the temperature and length of heat treatment, ${ }^{(53)}$ and the sequenre in which the two modalities are administered. (19) The importance of each of these factors varies among cell lines. (54) 
So far, a single coherent model to describe the synergistic interaction of hyperthermia with drugs or radiation has not emerged. For drugs, the mechanism is likely to be different for m.:h drug used, depending on the mote of action of the drug. For radiation the synergism with hyperthermia may result from the fact that the two modalities injure predominantly different targets, as indicated by the 5 phase scneitivity to iyperthermia and $S$ phase resistance to radiation for CHO cells. (55) For radiation, DNA (and perhaps the niclear membrane) is known to be of primary importance but the critical target for hyperthermia is more likfly to be a varipty of eromolecules ais/or cell membranes .

The range of results scen when hyperthermia is combined with radiation may be a function of the range of responses difirerent cell lines have to hyperthremia only. For example, the final slope ( $T_{0}$ ) of a hyperthermic survival curve varies by a factor of 10 among cell lines, while for radiation only, Do remains within a factor of two. Analytically, hyperthermia modifies the typical x-ray survival curve by decreasing the shoulder of the survival curve and by reducing the final slope of the survival cirve. For some cell lines the primary effect is on the shoulder of the curve while for others the slope is primarily affected. (19) This may imply that for differcnt cell lines, djfferent intracellular systems may be involved in the hyperthermic$x$-ray interaction.

Further variation in response among cell lines becomes apparent when examining the effect of sequence of hyperthermic and radiation treatments on survival. The work of $\mathrm{Li}$ and Kal ${ }^{(5 \dot{4})}$ typifies the extent 
of variation that is observec. They compared the response of HA-1 and EMT-6 cells to different sequences of treatment and varying lapses of time between treatments. In H-l preheating resulted in greater sensitization than postheating; for $5 . M T-6$ the opposite occurred. On the practical side, such data present a serious problem in deveiopment of clinical protocols. On the theoretical side, it is difficult to deveiop a model to account for the observed findings unless there are different targets in the cells. For instance if a radiatior refair enzyme is tinermally ustable in the EMT-6 cells this would account for postheating having a more lethal effect. However, Ben-Hur and Elkind showed that the interaction berween hyperthermia and $x$-irradiation must be more than simple inactivation of repair processes, since cells irradiated at $42^{\circ} \mathrm{C}$ have much lower survival rates than cells given the same radiation sose at $0^{\circ} \mathrm{C} .(27,98)$

In order to quantitate the radiation and hyperthermic tissue response in situ, Robinson et al. has defined a therma! enhancenent ratio (TER) as ". . the radiation sensitivity at an clevated temperature relative to that measured at (normal temperature)". (46) "btaining TER's boti for normal tissue and for tumors, he is thrn able to combine the concopt of synergistic interactiun with selective sensitivity by defining a therapeutio ratio as the ratio of TER for tumor to TER for normal tissue (i.e., Therapeutic Patio = TER tumor/TER normal tissue). Robinson has recently extended $l$ is scope to include hyoxic cells and has found that TER of hypoxic cells increases more rapidly with ircreasing temperature than does the TER for well oxygenated cells. That is, hypoxic cells are not only more sensitive that euoxic cells 
to hyperthermic treatment by itself; hypoxic cells also exhibit more synergism with radiation.

Very 1 ittle has been done comparing interations of hyperthermia with Tadiatjons of different linear energy transfer (LET). Cerner and teith ${ }^{(56)}$ have examined the reproductive survival of cho cells after I hour at $430 \mathrm{C}$ followed by $x \sim r a y$ or by $400 \mathrm{MeV}$ carbon ions (peak Iegion). They found that heat and $x$-radiation interacted synergistically while hyperthermia interacted in an additive manner with the carbon ion radiation.

4 Mode of Injury and Repai:

\section{a. Cell Survival}

The effect of exposing cells to elevated temperatures varies in a complicated manner with the duration and remperature of the cxposure. One of the mest commonly used endpoints for hyperthermia work is that of proliferative capacity. After treatment, if a cell is capable of generating a colony of more than 50 cells within 12 days at $37^{\circ} \mathrm{C}$, the cell is said to have survivec the treatment. For a constant exposure time, say of one hour, there is virtually no effect on survival (measured by proliferative capacity) up to a temperature of $41^{\circ} \mathrm{C}$, after which cell mortality increases with incrcasing temperatures. If, on the other hand, the temperature $\left(>41^{\circ} \mathrm{C}\right)$ is held constant while the duration of exposure is allowed to vary, most researchers have observed an initial period during which no or only slight cell death occurs followed by a period where cell survival appears to decrease according to an exponential relationship with time at temperature. 
Thus for a particular cell Iine, a family of survival curves can be obtained which will, in general, look like those in the figure below.

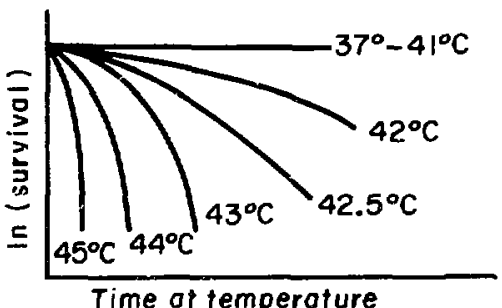

However, there is no simple function that will relate, for example, $1 / 2$ hour at $44^{\circ} \mathrm{C}$ to 1 hour at $43^{\circ} \mathrm{C}$. In fact the specifis physiologic response of surviving cells may be different at different temperatures. A variety of parameters must be me ssured at each temperature; results otcained for one temperature may not be generalized. This becomes apparent as results from various laboratories are compared.

The kinetics of cell mortality due to hyperthermic stress has been analyzed using the formalism Arrhenius originally developed in 1889 to meaure the influence of temperature on chemical reaction rates. The mortality rate ("inactivation rate") on the exponential region of the survival curve is substituted for the chemical reaction rate and plotted as a function of the reciprocal of the absolute temparature. $(55,59,61)$ The Arthenius plot for a number of cell 1 ines shows a constant slope with a break in the slope occurring at $42.5{ }^{\circ} \mathrm{C}$ (see amplified discussion in discussion section). 
There has been considerable effort to examine more subtle parameters of cell fingsiology than reproductive mortality. Specifically, biochemical properties, membrane changes, cell kinetics, and gross and molecular repair properties are currently under study in various laboratories.

b. Biochernistry

The e[feci of hyperthermia on several aspects of cell met aboitism and biochemistry has been studied and reviewed axtensively by strom et a1. (14) They obscrved that hyperthermic conditions resulted in reduced oxygen consumption ard inhibizion of DNA, RNA, and protein synthesis in tumor cells but not in normal cells. As a rule, the biosynethetic processes ate inhibited by themal treatment more than oxygen uptake, and formation of ribosomal RNA was preforential1y inhibited compared to formation of other kinds of RNA. (39) Levine and Robbins also measured glucose incorporation into polysaccharides and incorporation of choline and linoleic acid into lipids for heat treaced cells in sulture. (62) They found these pathways unaffected.

When Palzer and Heidelberger used specific cremical agrnts to block DNA andfor protein synthesis, Hela cells became less sensi':ive to hyperthermia than control cells. In contrast, when RNA synthesis was blocked, there was enhanced cell killing by heat treatment. ( 58$)$ Giovanella et al. (63) also found that suppression of RNA synthesis increased cell sensitivity to hyperthernia (L1210 leukenia cells).

One possible interpretation of these data would be that supranormal temperatures interfere with correct DNA and protein synthesis. If the normal progression through synthesis of these essential cellular macromolecules is suspended by other means, the cell is protected. 
If, on the other hand, some RNA syn hesis can proceed normally under elevated temperatures and is allowed to do so, the celi when returned to $37^{\circ} \mathrm{C}$ can immediately begin manufacture of proteins necessary to effect repair.

c. Suggested Mechanisms for Hyperthermic Cell Damage

The possible cellular constitıcnts which may sustain hyperthermic damage include the macromolecular systems of DNA, RNA, proteins, and membranes. They will be djscussed below in that order.

Since in many cases hyperthermia interacts synergistically with radiation, some inferences may be made concerring the cellular target cach modality interacts with. Synergism is defined as "the simultancous action of separate agencies which, together, have grcater total fffect than the sum of their individual effects". (123) Now, if heat and radiation each acted in the same manner on the same cellular target, one would expect the combined effect to be simpiy the sum of their individual effects. Similarly, if each modality interacted with ar entircly separate and independent target, one would again expect to see a simple additive effect between the two modalities. The existence or synergis:s between zadiation and hyperthernia implies that each modalicy acts in a different mamer on the same target. For example, while radiation may produce an effect directly on DNA by either direct action or by production of free radicals which in turn act airectly on the DNA), hyperthermia may act indirectly on the DNA by interacting with the chain of events which lead to DNA synthesis (i.e., causing membranes to become leady thereby depriving the cell of constituents necessary to repair damage caused by radiation, causing conformational 
changes which inactivate necessary enzymes, or by changing the structural rigidity of the protein-DNA complex and thereby interfering with resynthesis of damaged DNA). In this case, cellular changes produced by hyperthermia which may not have been lethal if hyperthermia alone was used, may become lethal when combined with radiation, yielding synergistic results.

A further argument against the direct role of DNA damage in hyperthermic cell $\mathrm{kil} 1 \mathrm{ing}$ is that the denaturation temperatures for DNA are well above the temperatures used in this research. For pH's ranging from 5 to 11 , the denaturation temperatures are $55^{\circ} \mathrm{C}$ or greater. (72) In addition, some authors have compared DNA taken from thermophilic and mesophilic bacteria and have observed similar melting temperatures. (73,74) In contrast, proteins taken from thermophilic microorganisms have exhibited higher denaturation temperatures than analogous proteins taken from mesophilic microorganisms. $(95,96)$

Overgaard examined ultrastructural changes following local in vivo hyperthermia treatments to murine mammary carcinomas. He noticed shrinkage of cellular nuclei and condensation of heterochromatin within six hours of treatment along with decreased granulation in the nucleoli. (75) These observations could possibly be due to loss of function in structural proteins associated with the DNA or to minor conformational. changes of the heterochromatin which result in progressive condensation.

Suppression of RNA synthesis has been observed to increase cell sensitivity to hyperthermia. $(58,63)$ Yet hyperthermic treatment itself has been observed to inhibit RNA synthesis and formation of mature 
ribosonai RNA's. $(39,76)$ the function of the RNA molecule in cell damage sustained by elevated temperatures is not yet clear but provides an interesting area for further research.

Although proteins also denature at higher temperatures than those conventionally used in hyperthermia research, it is possible that minor conformational changes may occur between 42 to $45^{\circ} \mathrm{C}$, Fuch small conformational changes could interfere drastically with the efficiency of important e.rzyme reactions, while not being observable in test tube evaluations of denaturation events. Damage at this levei mey possibly account for many of the effects seen in hyperthermic treatment. Loss of structural proteins could cause the chromatin condensation seen by Overgaard. $(75,100)$ Loss of function in metabolic enzymes might inhibit biosynthetic pathways. And inactivated repair enzymes couid provide the basis for synergistic interaction seen between hyperthermia and DNA specific agents such as $x$-ray and chemotherapeutic drugs. $(29,49,2,19,27)$

It has been suggested that the Arrhenius-type curve for cell mortality could yield inactivation energies that would correspond to particular target enzymes. $(55,20)$ However, to date, this approach has not proved fruitul.

Additional evidence supporting the concept of proteins as a rarget is that proteins of thermophilic microorganisms have developed higher denaturation temperatures than analogous proteins from mesophilic microorganisms. $(95,96)$

It is very likely that membrane structure and function is altered by clevated temperatures. Membrane fluidity is an important membrane property which allows membrane proteins to move laterally and rapidly 
in the plane of the membrane. $(77,78)$ The fluidity of the mombrane also affects protein transport, ${ }^{(78)}$ glucoside transport, $(79,80)$ and ion transport. (94) It may be that membranc fluidity will vary within a single membrane, as a function of lipid or protein clustering, which may in turn be necessary for specialized cell membrane or organelle functions. (8i), In ract it may be because of different required functions that nembrane composition varies fron cell to cell and organelle to organel le.

As temperatures increase, cell membranes may widergo a critical phase transition resulting ia cell injury. Several lipid components bave transitior temperatures in the range Erom 20 to $50^{\circ} \mathrm{C} .(84,14)$ Dep. - ing en the composition of the membrane, a composile phase transition in the range fiom 41 to $45^{\circ} \mathrm{C}$ is possible. Since neoplastic and norna? cells have difterent membrane properties: ${ }^{(82)}$ this hypothesis may explain for the selective sensitivity of neoplastic cells to hyperthermia. Evidence in support of this concept was found by Reeves. (64) In a cloned, heat-resistant ce!l 1 ine, he observed less leakage of uridine containing materials through the plasma membrane than in the normal, sensitive, parent 1 ine. Gerner and Russell found that after 1 hour at 430 , CHO cells lost polyamines to the extracellular mediur. Within a short time after treatment intracellular concentrations returned to norma1. (106) Using ultra-structure techniques, Overgaard observed pronounced lysosomal activity along wiln disaggregation of polyribosomes within, Tew hours after treatment. However, the nuclear envelr e did not show damage up to 96 hours after treatment. (75) 
Bacteria have been sinown to alter their membrane components when inc sbated at high temperatures. They incorporate fatty acids with longer chain lengths and higner degree of saturation. It is known that these properties increase membrane viscosity. Perhaps a compensatory mechanis exists to protect the bacterial membrane irom the melting effect at the elevated temperatures. $(92,93)$

There is evidence that cells ir culture can develop transient resistance by hyperthermia if allowed to recover for 2 hours or more at $37^{\circ} \mathrm{C}$ between treatments, $(85-87)$ or if treated at $42.5^{\circ}$ continuously.

This property could reflect the cells' abiluty to incorporate protective lipids into their membrancs.

Finally, it is possible for loss of membrane functions to nccur due to damage to membrane-bound proteins. It might prove difficult to separate injury uccurring exclusively to the lipid structure from injury accurring primarily to the membrane-bound protein. It seems that the research in this area has been limited to studies in the temperature range from 2 to $37^{\circ} \mathrm{C}$. In this temperature range the fluidity of the membrane is affected by temperature and thereby appears to affect the structural support given the membranous enzymes. $(88,89)$ That is, the thermostability of the lipoprotein complex may be more important than that of the lipid or protein by itself. (97)

The only evidence of membrane protern interaction at hyperthermic temperatures is indirect. Mondovi found that Ehrlich ascites cells which were exposed to $42.5^{\circ} \mathrm{C}$ for 3 hours stimulated an immune response when injected into host mice more effectively than did radiationinactivated cells. He suggests that heat treatment unmasks or múdifies 
an antigen in some undefined way. (91) Studying multiple immunologic parameters in a clinical setting, DeHortius et al. stated that ". . hyperthermia nay favorably alter the immune balance hetwen tumor and host in selected instances." $(90)$ His findings suggested support for Mondovi's hypothesis.

d. Cell kinetics

Cells vary in their thermal sensitivity during the cell cycle. As mentinned above, mid to late S-phase cells appear to be most srnsitive to heat treatment, $(55,57,58)$ with the exception of pig kidncy cells where no differential sensitivity was found. (64) It is perhaps a result of the 5-fitase sensitivity that exponentially growing colls have groatcr sensitivity to heat than do plateau phase rells. $(62,65)$

Cell kinetics during and following hyperthrrmia has born studied using autoradiographic $(65,67)$ and flow cytometry techniques. $(68-71)$ Post-exposure proliferation rates have also been rxamined. $(57,68)$ Kal et al. Teport that 1 hour at $43^{\circ}$ delays growth of EMT-6 for 6 hours and causes a block in S as well. (67) Schlag observed a 4 ,our growth delay in Chinese hamstel lung cells treated for 30 minutes at $42^{\circ} \mathrm{C}$. If he treated cells for an hour at $42^{\circ} \mathrm{C}$ he observed with a cytofluorograph that cells appeared to be blocked in $S$ for 4 hours. (70) One of the aims of this dissertation is to better detail what part of the cell cycle is affected by the growth delay at different temper atures and to compare kinetics for equal survival levels obtained by use of different temperatures. 
e. Repair

Cellular repair of hyperthermic damage has been studied at three levels: (1) the effect of hyperthermia on the ability of colls to repair single- and double-strand DNA breaks ciused by inriring radiation; $(27,98-102)$ (2) survival studies designed to infirate rrpair of sublrihal and potentially lothal damage; $(20,51,57,87)$ and (3) survival studies designed to masure induction of a state ni thermotolerance. $(20,61,64,85-87)$ The following discussion will consider each of these approaches, respectively.

By incubating cells at supranormal temperatures betwenn fractinnater x-ray doses and by varying the $x$-ray dose rate at elevated tomperatures, Ben-lius and Elkind demonstrated that hyerthermia inhibits repair of sublethal $x$-irradiation damage. $(27,101)$ To see $i t$ the repair inhibitation was due to unrepaired single-strand breaks, they ax minfd the effect of hyperthermia on the rejoining rate of sinfle-strand DNA breaks and danage to the DNA complex. $(98,99)$ They observed that at $42^{\circ} \mathrm{C}$, rejoining of $x$-ray induced single-strand DNA broaks (SSB) proceeds more rapidly than at $37^{\circ} \mathrm{C}$. However, they noted that incubation at $41^{\circ} \mathrm{C}$ and $42^{\circ} \mathrm{C}$ after irradiation caused the DNA comnlex to r:pair more slowly and atypically. They concluded that hyperthermia may canse changes in the higher order chromatin structure (i.e., tortiary, quaternary structure? or in the nucleo-protein or chromatin-nuclear membrane structure, which interfere with repair of $x$-ray induced DNA damage. $(98-100)$

Corry saw no significant difference between rejoining of $x$-ray induced SSB in control cells and those pre-incubated at $43^{\circ} \mathrm{C}$. However, 
using very high doses, he did see a reduction in the rejoining rate of double-stranded DNA breaks (DSB) when preheated at $43^{\circ} \mathrm{C},(102)$ Significantly, he mentions that "neither DSB nor SSB arise from the hrat treatment alone in the temperature range $41-46^{\circ} \mathrm{C}$, and the frequency of DSB induction by radiation remains unaffected by heat treatment." However, the data for these observations is not presented in the paper.

The concepts of subethal and potentially lethal damage to cells treated with hyperthermia are exactly analogous to chose developed in rariation biology. (103) That is, thr presence of a shoulder (D ${ }^{\text {) }}$ on the survival curve of heat treated cells indicates the capacity of the cells to accumulate "sublethal" damage. When this capacity is saturated, any further damage is "potentially lethal" resulting in the exponential portion (slope-- ${ }_{0}$ ) of the survival curve.

Bépair of sublethal danage is observable by re-establisiment of the shoulder in a survival curve. Recovery from potentially lethal damage is observable by an increase in survival, with time, at $37^{\circ}$, after exposure. Recovery of potentially lethal damage (PLU) from heat has been reported for HAl cells and seems to be highly dependent on nutritional factors. (28) Use of sone drugs also appears to stimulate repair of PLD. (57) our experiments suggest that otherwise untreated $\log$ phase cells may also show recovery from PLD due to hyperthermia. Recovery from heat induced sublethal damage has been well demonstrated. $(20,51,87)$ It is manifested in the reappearance of a shoulder when cells are given an initial hyperthermic treatment, allowed to recover at $37^{\circ} \mathrm{C}$, and given a graded series of second doses. 
In addition to a reappearance of the shoulder upon a second hyperthermic treatment, the final slope $\left(T_{0}\right)$ of the exponential region of the survival curve is greater than the single exposure $T_{0}$. That is, after the cells' capacity to arcumulate sublethal damage has bren re-saturated, they accumulate lethal damage at a slower rate than they did for the single exposure condition. The term "thermotolerance" has been suggested to fescribe this phenomenon $(61,85,86)$ and it has bren observed in many cell systems (for review see Ref. 2). For cemperatures less than $43^{\circ} \mathrm{C}$, thermal tolerance can be induced during continunus treatment in some systems. $(20,19,2)$ Gerner has termed this Type II thermotolerance while the thermotolerance which is dependent on split exposures is notated Type I. (105)

With one exception, the induced thermal resistance has been transient. Harris found that the thermal resistant trait p'arsisted in the progeny of resistant cells and was stable for 15-24 serial passages ( 6 months) without additional heat treatment, after which a gradual decline in thermotolerance was observed. (61) comparing thermotolerant clanes of pig hidney cells to the sensitive parental line, Reeves ${ }^{(64)}$ found the resistant lines leaked significantly smaller amounts of uridinecontaining material through the cell membrane and that they began synthesis of macromolecular compounds more quickly after treatment than did the sensitive parental line. It is unfortunately not possible to generalize these results because of the transient nature of the thermotolerant state in other cell lines. 


\section{RA'IIIONALE}

The 9L-rat gliosarcoma system had been in use for several years at Liwrence Berkeley Laboratory when I started to examine the effects of hypertherma. The fact that these cells can be cultured either in situ, in vivo or in vitro makes them extremely useful as a cellular biological tool.

During the initial characterization of tie cell survival response (by proliferative capacity) to several temperatures $\left(37.0-45.0^{\circ} \mathrm{C}\right.$ ) we noticed (qualicatively) a delay in the growth rate of surviving colonies which became progressively longer with increasingly severe hrat treatmrnts. This observation led to interesting questiens concerning the manner in which heat affected growth of 1 iving cells. Parameters of interest include length of delay, changes in generation time, and induction and duration of blocks at certain phases of the cell cycle.

The main emphasis of our work is the comparison of the ef fect of different temperatures and exposure times on perturbations in cell cycie kinetics. Although other researchers have looked at perturbations in celi cycle kinetics at one or another temperature, we are not aware that anyone has yet compared cell kinetics resulting from colls troted at several temperatures and exposure times. It is difficult to develop the basis for comparison since there is no clear concept of dose in hyperthermic treatment. That is, how long at, say, $43^{\circ} \mathrm{C}$, corresponds to 1 hour at $42.5^{\circ} \mathrm{C}$ ?

For our work we suught to use iso-survival levels as the basi; for comparison. For example, survival curves indicate that either $75 \mathrm{~min}$. at $12.5^{\circ} \mathrm{C}$ or 45 minutes at $43^{\circ} \mathrm{C}$ reduce cell survival to $75 \%$. By 
repeating these exposure conditions for kinetic studies we aimed to reduce survival to an iso level at the time the kinetic measurements were madc.

Other researchers have observed that a state of tolerance to hyperthermic exposure can be induced in cells if they are allowed to recover at $37^{\circ} \mathrm{C}$ for some time between heat exposures (see introduction and discussion sections). We were also able to observe a thermotolerant effect in ol cells using heat exposures that yielded the iso-survival levels used in the kinetic studies. Because many cells are differentially sensitive to heat in various phases of the cell cycle, we hoped to correlate post hyperthermic treatment kinetics with the interval that cells rested at $37^{\circ} \mathrm{C}$ between split exposure treatments. For example, if cells accumulate in a heat-resistant phase of the cell cycle in response to the initial hyperthermic exposure, it would not be surprising to see increased resistance to killing by high cemperatures.

Clinically, many glial cell tumors tepresent a class of malignancies which are resistant to successful treatment using conventional therapies. (109) A glial cell tumor system therefore provides a good system on which to study the effects of a new treatment modality s.ach as hyperthermia. The $9 \mathrm{~L}$ tunor model has the ability to be grown and treated in vivo, in situ, and then assayed quancitatively in vitro. Beca...e of the difficulty is producing controlled hyperthermia conditions in the brain at the beginning of this work, I have dealt entirely with cells maintained in vitro. However, the recent development of hyperthermia producing equipment ${ }^{(107)}$ should make the extension to 
in vivo-in vitro experiments possible. In fact, some work has already begun along these lines. (108) 


\section{MATERIALS AND METHODS}

Tumor cells used in these experiments were originally obtained from a malignant tumor produced in the brain of CD Fischer rats by

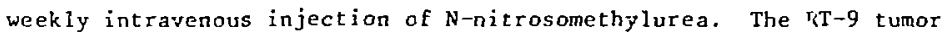
(from which $9 L$ cells were derived) was histologically classified as a high-grade astrocytana which was stable over many passages in tissue culture. The tunor was" . . extreme?y cellular with moderate pleomorphism and nuclei varying in shape from oval to round with a diffuse chromatin pattern and rare prominent basophilic nucleoli. The interstitium was finely fibrillar and composed of glial fibrils. Numierous mitoses were present, a few of thich were atypical. Stellate areas of necrasis were bordered by palisading tumor cells. There was also prominent palisading of cells about vessels. Increased vascularity and marked endothelial proliferation werc also present."(116) Cells were supplied to us by the Brain Tumor Research Center, University of California, School of Medicine, San Francisco, California, where the cells were developed into an in vivo-in vitro model. The cells are now designated $9 \mathrm{~L}$ tumor cells, and in solid tumors they histographically appear as a mixed gliosarcoma.

The experiments described in this dissertation used cells grown in vitro. Stock cultures were maintained in monolayer growth in $75 \mathrm{~cm}^{2}$ plastic tissue culture flasks (非3002, Falcon Plastics, Oxnard, CA) with 15 ml of Eagle's minimum essential medium (Grand Island Biological Co., Grand Island, NY) with Earle's Salts and $20 \%$ fetal calf serum. Initially all cultures were grown in medium containing antibiotics (penicillin, $50 \mathrm{U} / \mathrm{ml}$; streptomycin, $50 \mu \mathrm{gm} / \mathrm{ml}$ ). Hovever, it was found 
that alternating between antibiotic free medium and medium containing both antibiotics and an anti mycoplasmic agent ( $1 \%$ Knamycin) resulted in better protection against m:coplasma. Two culture series were carried forward sinultaneously, alternating in staggered fashion between the media, so that Kanamycin free cells werp always available for experjments. Thus possible toxic interaction between Kanamycin and hyperthermia was avoided.

Cells for experiments were seeded from log phase stock crlls at $10^{5}$ cells in $5 \mathrm{ml}$ of mejium per $25 \mathrm{~cm}^{2}$ culiure flask (Falcon Plastics), 2 days prior to an experiment. Medium used in experiments contained antibiotics which have been reported not to interact with hyperthermia in the concentration mentioned above; $(117,118)$ anti mycoplamic agents were not used in experimental media. This procedure yielded about $5 \times 10^{5}$ asyachronous, $\log$ phase cells per flask in monolayer on the day of the experiment.

\section{HYPERTHERMIC TREATMENT}

Cells were subjected to hyperthermic treatment in the $25 \mathrm{~cm}^{2}$ flasks after sealing with Parafilm (Mara Products, Neenoh, WI). The flasks were layed on the bottom and middle shelf of a staridard test tube rack and immersed in a horizontal position an a thermostatically controlled, constant temperature, stirted water bath accurate to $\pm 0.05{ }^{\circ} \mathrm{C}$ (Lo-Temptrol Riodel 154, Precision Scientific Co.) for 1 to 12 hours (Plate 1).

Upon removal froun the water bath, the supernatant media was removed and the number of cells in the supernatant that had detached from the plastic surface were counted (Coulter Counter, Model B, Coulter 
Elertronics, Hialeah, FL). In separate experiments, suivival characteristics of the cells in the supernatant were determined.

The $\mathrm{pH}$ of the supernatant media was monitored as a function of time and temperature (Beckman Model $\mathrm{G}$ or Corning Digital $109 \mathrm{pH}$ meter) in order to rule out secondary stress on the cells due to $\mathrm{p}^{\mathrm{h}}$ changes with time at high temperatures. At all temperatures, pli remianed constant at $7.4 \pm 0.1$ urits.

Ce1ls were rcmoved from the surface of the flask with $0.03 \%$ trypsin-EDTA ( $3-5$ minutes), pelleted by centrifugation, resuspended, diluted, counted on a hemacytometer, and secded into $60 \mathrm{~mm}$ diameter plastic petri dishes (Falcon Plastics) at an appropriate concentration. Five replicate dishes were seeded for each dilution. At high survival levels, the total number of cells per dish was kept at $10^{4}$ by addition of the appropriate number of heavily irradiated (3600 rad of $150 \mathrm{kV}$ $x$-rays) feeder cells. Cells were incubated at $37^{\circ} \mathrm{C}$ in $35 \% \mathrm{CO}_{2}$ environment for 10 to 12 days.

Survival was determined by counting colonies of more than 50 cells after staining dishes with Hematoxyl in or Methylene Blue. Each stainable colany was assumed to represent the progeny of a single cul which has survived the heat treatment. A colony size of 50 healthy cells was chosen for case of comparison with the data of other investigators who also used this criteria. Elkind and Sutton showed that counting essentially all stained areas rather than those colonies with 150 or more cells shifted the survival curve by only a small amount. (104) Their data suggests that the exact lower 1 imit used as criteria for a surviving cell is not coo critical. (103) 
Each experiment consisted of two replicate flasks per point. Each flask was seeded into 2-3 dilution sets of $f$ ive dishes and each experiment was repeated at least twice so that most points on the survival curves represent an average of four flasks ( $30-40$ dishes).

Hyperthermic effects were also determined by the cell's ability to exclude trypan blue vital stain ( $0.4 \%$ by volume) mixed v:v with $0.5 \mathrm{ml}$ of cell suspension immediately after hyperthermic treatment. The percent of cells that took up the stain was determined after incubation for 5 minutes at $37^{\circ} \mathrm{C}$. Approximately 100 cells were counted.

In order to observe the thermotolerant effect, flasks were initially treated at $43.0^{\circ} \mathrm{C}$ to one of four survival levels $(75 \%, 25 \%, 5 \%, 1 \%)$, a: lowed to recover for 3 hours at $37.0^{\circ} \mathrm{C}$, and then given graded second exposures to hyperthermia. The cells were then assayed for proliferative capacity as described above.

I I. THERMAL DOSTMETRY

The sensitive portion of a 22 gauge thermistor needle probe (resistance 1200 ohms at $37^{\circ} \mathrm{C}$ ) was placed at the media--plastic interface of a $25 \mathrm{~cm}^{2}$ Falcon flask containing $5 \mathrm{ml}$ of complete media. The flask was then placed into the water bath and heating and cooling curves were measured for temperatures from $37.0^{\circ} \mathrm{C}$ to $45.0^{\circ} \mathrm{C}$ under conditions identical to the experimental exposure conditions.

The change in resistance of the thermistor with remperature was measured with a Keithley digital electrometer (Model 616), Keithley Instruments, Inc., Cleveland, Ohio, and permanent tracings were made by recording the d.c. output of the electrometer on a Grass Model 7 Polygraph (Grass Instruments, Inc., Qunicy, Mass.). 
Sixty-three percent of the temperature change was reached witin l min. for the highest experimental temperature $\left(45.0^{\circ} \mathrm{C}\right)$. At the lowest temperature $\left(39.0^{\circ} \mathrm{C}\right), 63 \%$ of the temperature change- was reached within $0.5 \mathrm{~min}$. For all temperatures, the full change in temperature was anieved within 5 mir.

\section{I11. FLOW MICROFLUOROMETRY}

Flasks of cc.lls were seeded at $10^{5}$ cells per flask two days prior to heat ireatment. The cells were then subjected to hyperthermia using $42.5^{\circ} \mathrm{C}$ or $43.0^{\circ} \mathrm{C}$ for times appropriate to reduce survi.al to $75 \%, 25 \%$, or $2.5 \%$. Upun removal from the water bath, flasks were dried, caps loosened, and flasks placed back into a 370 incubator for varying periods of time. Cells were prepared for FMF according to the method of $\mathrm{Cr}$ issman, (112) and stained with Chromomycin $\mathrm{A}_{3}$ or Propidium indide (PI). Samples were analyzed on a locally constructed flow microfluorometer. The electronics were of the Steinkamp, et al. design (113) and the flow cell was after Molm's design. (114) A laser excitation wavelength setting of $514 \mathrm{~nm}$ for Propidium iodide or $457 \mathrm{~nm}$ For Chromomycin $A_{3}$ stained cells was used.

The stains used bind to the DNA of the cell and fluoresce when illuminated by 1 ight and an appropriate excitation wavelength. The intensity of the fluorescence is taken to be proportional to the amount of bound stain which is, in turn, a function of the amount of DNA in the cell. Chromomycin $\mathrm{A}_{3}$ belongs to a class of antibiotics which has a high specificity for helical DNA but not for RNA. Chromomycin $A_{3}$ appears not to cause uncoiling of the DNA double helix (119) and does not intercalate into DNA. (120) Used at a concentration of $100 \mu \mathrm{g} / \mathrm{ml}$, 
Chromomycin $A_{3}$ essentially stains to full intensity within 20 min. (111) Propidium iodide is an analogue of ethidium bromide which quantitatively intercalates into double-stranded regions of DNA and RNA (121) (so RNAase is used in the preparation of this stain).

The intensity of the fluorescent signal is measured with a photomultiplier tube and a frequency histogram of the 1 ight output Enr individual cells is constructed and stored. Since DNA content is presumed to be directly related to the position of a cell in the cell cycle, the histcgrams can be interpreted to represent the distribution of cells in various stages of the cell cycle.

Several conputer programs were considered for analys is of the FMF histograms. However, existing, avaijable programs failed either to accomorlate the perturbed $S$ populations or to account for overlap of the $S$ region into the $G 1$ and $G 2+M$ regions. So, DNA histograms were analyzed by use of a mechanical planimerer. The $f_{1}$ and 62 peaks of the histogram were represented by one leg of a right triangle. The hypotenuse represented the leading edge of the Gl peak or the trailing edge of the G2 peak; the base of the triangle was formed by the zero level (see Fig. 1). The area of the G1 and G2 peaks were complted by doubling the area of the appropriate triangle. To allow for the jact that $S$ phase cells extend into the Gl and $G 2$ regions, the hypotenuse of the triangie is aligned with the upper portion of the histogram. The extent to which there is increased spread at the base of the triangle is attributed to $S$ plase cells by inclusion of the spread in the total area of the histogram and exclusion of the spread from the calculation of $G 1$ and $G 2$ regions. 
The placement of the $G 1$ and $G 2$ peaks bears some comment. Immediately upon viewing the histogram, the two maxima are discernible; these are referred to as the apparent $G 1$ and $G 2$ peaks. However: closer examination of the histogran reveals that the apparent 62 peak usually does rot occur at twice the intensity of the apparent Gl peak, although cells in C2+M should have twice the DNA content of cells in Gl. The asymmetric shape of the $S$ contribution which adds to these peaks results in shifting the apparent peaks toward the cnnter of the histogram. An atempt was made to place the pcaks at their true position by use of the follnwing protocol.

The location of the apparent $G 1$ peak $\left(G l_{A}\right)$ on the abscissa was doubled to indicate the expected location of the $G 2$ peak. Thr true G2 roak $\left(62_{T}\right)$ was placed midway between this value and the apparent GI prak $\left(G 2_{A}\right)$. The true $G 1$ peak $\left.(G)_{T}\right)$ was then placed at $1 / 2$ the true G2 value (Fig. 1). That is,

$$
\begin{aligned}
& \mathrm{G} 2 \mathrm{~T}=\mathrm{G} 2 \mathrm{~A}+\frac{2 \times G 1_{A}-\mathrm{G} 2 \mathrm{~A}}{2} \\
& \mathrm{Gl} \mathrm{T}=\frac{G 2 \mathrm{~T}}{2}
\end{aligned}
$$

Plainimeter analysis then resulted in repeatable values for $G 1, S$, and $G 2+M$. Surprisingly, the $S$ value renained relatively inseisitive to the exact pasitioning of the true peaks as long as G $T$ was constrained to be $2 \times G 1_{T}$. Of course, the $G 1$ and $G 2+M$ values were dependent an the cxact positioning of the true peaks. 


\section{AUTORADIOGRAPHY}

\section{A. LABELING INDEX (I.I)}

Flasks of cells were subjected to hyperthermic treatment according to the same regimen as for the FMF work. However, after speriding varying periods of time at $37.0^{\circ} \mathrm{C}$ after heat treatment, cells were exposed to $2 \mathrm{ml}$ of medium containing $1 \mu \mathrm{Ci} / \mathrm{ml}$ of tritiated thymidine ( ${ }^{3} \mathrm{H}-\mathrm{TdR}$ ) (specific activity, $6.7 \mathrm{Ci} / \mathrm{mM}$, Now England Nuclear). Possible diluti:n of thymidine pool in the cell was checked by repeating the experiment using an alternate precur solecule, tritiated deoxyuridine (spec. act. 15-30 Ci/mM, New England Nuclear). After 15 minutes incubation at $37^{\circ} \mathrm{C}$ with ${ }^{3} \mathrm{H}-\mathrm{TdR}$, cells were washed twice with Earle's basic salt solution (BSS). Harvested cells were pelleted and resuspended in 5 drops of BSS and one drop was spread on cach of four microscope slides. The slides were air dried, fixed in absolute methanol for 15 min., rinsed in distilled water for $1 / 2$ to 1 hour and air dried. Slides were then dipped in Kodak NTB-2 nuclear emulsion and exposed at $4^{\circ} \mathrm{C}$ in light tight boxes containing Drierite for 8 days. The autoradiographs were developed for $6 \mathrm{~min}$. in Kodak $\mathrm{D}-170$ developer and stained for $10 \mathrm{~min}$. in Hematoxylin. Cells with more than 5 grains were counted as positive. This procedure closely follows the work of Nomura et al. (1i4).

\section{B , PERCENT LABELED MITOSES (PIM)}

Media was removed from flasks, pooled, and supernatant cells removed by centrifugation. Then cells were exposed to 2 ml medium containing $1 \mu \mathrm{Ci} / \mathrm{ml}^{3} \mathrm{H}-\mathrm{TdR}$ for 15 minutes prior to heat treatment. The monolayers were washed twice with BSS and 5 ml of the pooled 
original medium in which they had been growing was replaced (so that nutrient depletion in the mediun at the time of heating would not be different from other experiments). Cells were treated at $43.0^{\circ} \mathrm{C}$ to $75 \%$ and $2.5 \%$ survival. After hyperthermic treatment, flasks were replaced in a $37.0^{\circ} \mathrm{C}$ incubator. Each $1-1 / 2$ hours autoradingt aphs wert prepared. Finaliy, the percent labelled mitoses were scored for each point. 
RESULTS

I. SURVIVAL CURVES

The effect of temperatures from $39.0^{\circ} \mathrm{C}$ to $45.0^{\circ} \mathrm{C}$ on surviral of $9 \mathrm{~L}$ cells grown in monolayer is shown in $\mathrm{Fig}$. 2. At $42.0^{\circ} \mathrm{C}$, the shoulder region is not unequivocably distinguishable. Exposure to temperatures of $42.5^{\circ} \mathrm{C}$ and abore resulted in distinct shoulder and exponential regions ct the survival curve. Temperatures of $39.0^{\circ} \mathrm{C}$ or $41.0^{\circ} \mathrm{C}$ for as fong as six hours produced no detectatle effect on clonogenic cell survival. All survival curves were normalized to the control plating efticiency, determined individually for each experiment. Control plating efficiencies were typically 70 percert.

The survival curves in Fig. 2 can be described by the parameters $\mathrm{T}_{\mathrm{p}}, \mathrm{T}_{\mathrm{q}}$, and $\mathrm{n}$, analogous to the radiation curve parameters $\mathrm{D}_{\mathrm{o}}, \mathrm{D}_{\mathrm{q}}$, and $n$. For a given temperature, $T_{0}$ is the time required to reduce survival by a factor of $1 / e$ in the exponential region of the survival curve and is determined by a least square fit to data points where survival is less than $30 \% . T_{q}$ is the quasithreshold time, the time at which a back extrapolate of the exponential portion of the survival curve interserts a survival traction of 1.0. $n$ is the extrapolation number, the point at which the back extrapolate of the exponential region intersects the ordinate. The manner in which these parameters vary with temperature is shown in Table I and Fig. 3. The quasithreshold time ( $T_{q}$ ) and the exirapolation number $(n)$ both show a discontinuity at $42.5^{\circ} \mathrm{C}$ and $43.0^{\circ} \mathrm{C}$ respectively (Fig. 3 ).

An Arrhenius-type plot of the rate of inactivarion (1/To) vs. the reciprocal of the absolute temperature in degrees Kelvin or in 
degrees centigrade is shown in Fig. 4. From the Arrhenius equation:

$$
d(\ln k)=(y / 2)\left(d T / T^{2}\right)
$$

where $k$ is the rate of celluiar inactivation; $T$ is the temperature in ${ }^{\circ} \mathrm{K}$; and is the macroscopic activation energy for the sum of the chemical reactions that produce cell inactivation. Integration yiclds:

$$
\ln \left(\mathrm{k}_{1} / \mathrm{k}_{2}\right)=1 / 2\left(1, \mathrm{~T}_{2}-1 / \mathrm{T}_{1}\right)
$$

-and the activation energy between any two temperatures is then

$$
=2 \ln \left(k_{2} / k_{1}\right) \cdot\left(1 / T_{1}-1 / T_{2}\right) .
$$

The activation energy is also obtained fom the slope of the Arrhenius plot,,$/ 2$. Our data clearly shows a rigificant change in $\mu$ at $43.0^{\circ} \mathrm{C}$ (Fig. 4).

I I . SUPERNATANT CELLS

For various heat treatments, the number of cells found in the supernatant (Fig. 5) did not increase over a period of 6 hours during treatment at remperatures of $39.0^{\circ} \mathrm{C}$ to $42.0^{\circ} \mathrm{C}$. For cells grown in monolayer culture, the release of cells into the supernatant medium is usually a sign of cytotoxicity or approaching cell death. After four hours at $43.00 \mathrm{C}$, the number of cells in the supernatant had doubled and by 6 hours had quadrupied (evident in unnormalized data). However, the $43.0^{\circ} \mathrm{C}$ survivai curve illustrated in Fig. 2 was not af fected since survival was assessed within 3 hours at $43.0^{\circ} \mathrm{C}$. At $44.2^{\circ} \mathrm{C}$, the percentage of total cells appearing in the supernatant increased rapidly after 2 hours. Within one hour at $45.0^{\circ} \mathrm{C}$, supernatant cells had increased 
by a factor of 8 and continued to increase co 80 times the control value by 6 hours at $45.0^{\circ} \mathrm{C}$. It seems likely that the inc sease in supernatant cells represents cells which have detached from the growing surface of the tissue culture flux during heat treatment. It is worth noting that celis did not begin to detach matii after the time at each temperature necessary for construction of the survival curves shown in Figure 2 .

An attempt was made to construct a separate set of survival curves for supernatant cells at each temporature. The control plating efficiency of supernatent cells averaged $17 \% \pm 2.9 \%$ (Standard Error), indicating a low clonogenic potential for suspended cells even when not heated. The low control plating efficiency prevented construction of statistically significant sirvival curves.

III. DYE EXCLUSION MEASUREMENTS

In addition to measuring cell survival by froliferative capacity, the exclusion of trypan blue dye was used as an indicator of cell viability for attached cells. Exclusion of trypan blue proved a much less sensitive indicator of cell integrity than did colony formation and data did not correlate well between the two assays. Harris (115) reported a similar lack of correspondence between mortality measured by trypan blue exclusion and colony forming ability for pig kidney cells. However, the number of dead cells as indicated by trypan blue viability studies correlated extremely woll with the percent of cells detaching from the surface of the culture flask (Fig. 6). Since both trypan blue exrlusion and cell detachment provide a measure of one aspect of cell membrane integrity, defects in this membrane function 
appear to irfluence survival only at severe exposures, where survival is less than $0.1 \%$ by colony formation. Fig. 60 shows that these effects become important after 3 to $3.5 \mathrm{hl}$ at $43.0^{\circ} \mathrm{C}$ and after 1.5 to $2 \mathrm{hr}$ at $44.2^{\circ} \mathrm{C}$. There is no effect for up to 12 hours of continuous exposure at $42.0^{\circ} \mathrm{C}$.

IV. DOUHLE HYPERTHERMIC EXPOSURE

When cells are given a single initial cxposure to hyperthermia and then returned to $37.0^{\circ} \mathrm{C}$ for three hours, followed by graded second exposures to the same hyperthermic temperature, the final slope of the survival curve is greater than that from the single exposure condition. Our results for 4 different initial exposure times at $43.0^{\circ} \mathrm{C}$ are shown in Fig. 7. Th for the single exposure condition is 16.8 minutes. If cells are initially treated to $75 \%$ survival $\left(s_{i}=75 \%\right)$ the $T_{0}$ for the subsequent exposure is 108 minutes. For initial survival levels of $25 \%, 5 \%$, and $1 \%$, the scond exposure $\mathrm{T}_{\mathrm{o}}$ 's are measused at 39 , 55 , and 64 minutes respectively. Although the last three values may not be statistically different, they follow a trend established by other data (2) which suggests that the second exposure To increases with decreasing initial survival (Fig. 7) in the exponential region. There does not appear to be a re-establishment of the shoulder region of the curve although there appears co be some increased cell survival (resembling PLD) for re-exposure after an $S_{i}$ of $5 \%$ or $1 \%$.

The increase in $I_{0}$ indicates that cells are not killed as readily by hyperthermic treatment upon a second exposure. The extent of this increased resistance to heat treatment can be indicated by taking the ratio of $\mathrm{T}_{0}$ resulting rrom a single hyperthermic exposure to $\mathrm{T}_{0}$ 
of the split exposure conditinn. This ratio has been termed Thermotolprance (TT). (2) That is:

$$
\mathrm{TT}=\frac{\mathrm{T}_{0}(\text { split exposure })}{\mathrm{T}_{0}(\text { single exposure })}
$$

A subscript can be used to denote the survival level ( $s_{i}$ ) that the split dose population was initially reduced to. A superscript indicates the temperature used in centigrade degrees. For example:

$$
\mathrm{TT}_{75 \%}^{43}=\frac{108 \mathrm{~min} .}{16.8 \mathrm{~min} .}=6.42
$$

where $\mathrm{S}_{i}=75 \%$ and the temperature was $43.0^{\circ} \mathrm{C}$.

When $S_{i}$ was high enough to remain within the shouider region of the single exposure curve, the resulting thermal tolerance was relatively high. When $S_{i}$ was in the exponential portion of the single exposure survival curve, thermal tolerance increased with decreasing $\mathrm{S}_{i}$. For example, for $\mathrm{S}_{\mathrm{i}}=25 \%, 5 \%$, and $1 \%, \mathrm{TT}=2.32,3.26$, and 3.83 . This observation has been made on the exponential region for other cell 1 ines as well (Fig. 8). (2)

\section{KINETIC STUDIES}

A. FLOW MICROFLUORG ETRY

Sample histograms resulting from flow microfluorometric analysis are shown in Figs. 9 and 10 . Two temperatures and three survival levels were emphasized. $43.00^{\circ} \mathrm{C}$ and $42.50 \mathrm{C}$ tamperatures were chosen because the break in the Arrhenius plot occurred at $43.00^{\circ} \mathrm{C}$ and the shoulder width was maximal at $42.5 \circ \mathrm{C}$. In addition, these temperatures lie within the clinically important range. The survival levels of 
$75 \%, 25 \%$, and $2.5 \%$ represent the various regions of the survival curve. Table II shows the hyperthermic exposure interval required to reduce survival to the required level for each temperature.

For each temperature and survival level, the first change noticeable in the histogram is a relative accumulation of cells in the $S$ region of the histogram. The length of time that passes before this accumulation is noticeable varies depending on the survival level to which the cells were trejted and the temperature used to achieve that survival level. At $43.0^{\circ} \mathrm{C}$, for $75 \%$ survival, the accumulation of cells in the $\mathrm{S}$ region is apparent 6 hours after treatment. For 25\% survival level, an accumulation of cells in the $S$ region becomes noticeable at 9-12 hours post treatment. For $2.5 \%$ survival, the relative increase in $\mathrm{S}$ phase cells is not observabie until 24 hours after hyperthermic treatment has terminated. That is, for a constant temperature $\left(43.0^{\circ} \mathrm{C}\right.$ in this case), as survival decreases, the post treatment interval lengthens before a change in the FMF histogram distribution is noticeable.

This pattern is repeated for $42.5^{\circ} \mathrm{C}$. For the $75 \%$ survival level, the accumulation of cells in the early $\mathrm{S}$ region is apparent 3 hours after treatment. For $25 \%$ survival, a mid-S accumulation is noticeable at 6 hours whereas for $2.5 \%$ survival the cell accumulation is still in early $S$ at 6 hours post treatment.

A graphical representation of the $\mathrm{Gl}, \mathrm{S}$ and $\mathrm{G} 2+\mathrm{M}$ populations is shown for $75 \%$ survival using $43.0^{\circ} \mathrm{C}$ temperatures in Fig. ll. Control values are $50.0 \%, 34.1 \%$ and $15.8 \%$ for $S, G 1$, and $G 2+M$ respectively. The accumulation of cells in $S$ is accompanied by a relative depletion of cells in G1 and G2+M. By 12 hours the cohort of accumulated cells 
have moved to $G 2+M$ and after 30 hours the distribution is approaching normal. This pattern of redistribution through the cycle following the accumulation of cells in $\mathrm{S}$ is seen for both $43.0^{\circ} \mathrm{C}$ and $42.5^{\circ} \mathrm{C}$ for all survival levels measured.

Since the accumulation of cells in $S$ leads the progression of cells through the rest of the cell cycle, it can be useful to compare only the changes in the $S$ fraction for different survival levels achieved with the use of either $43.0^{\circ} \mathrm{C}$ (Fig. 12) or $42.50^{\circ} \mathrm{C}$ (Fig. 13). This presentation emphasizes that with decreasing survival fraction, the length of dely increases ( $i . e .$, the time increases before the expected accumulation in $s$ is observed).

To assure that the cell cycle histograms were not being sufficiently biased by population increases or decreases during the observation periods, cell counts were taken throughout the posi treatment time during which kinetic stuiles were conducted (Figs. 14 and 15). At $43.0^{\circ} \mathrm{C}$ cell populations remained constant at 30 hours post treatment for the $25 \%$ survival level. For $75 \%$ survival, cell numbers began to increase rapidly after 10 hours post treatnent. This may explain the sudden drop in percent cells in $S$ at the $75 \%$ survival level in Fig. 12. For $2.5 \%$ survival a $37 \%$ decrease in cell numbers occurred by 30 hours after treatment.

At $42.5^{\circ} \mathrm{C}$ the cell population count remained constant for 9 hours post treatmert at the $75 \%$ survival level. At $25 \%$ survival, the cell numbers did not change until more than 21 hours post treatment, while for the $2.5 \%$ survival level, a $20 \%$ drop in cell numbers was observed 
21 hours after treatment and a $20 \%$ increase in cell counts was noted by 29 hours post treatment (Fig. 15).

A control growth curve indicates a population doubling time of $13-1 / 2$ hours.

Figures 16-18 illustrate the difference in kinetic response seen for 3 iso-survival levels achieved using either $42.5^{\circ}$ or $43.0^{\circ} \mathrm{C}$. For all survival levels, the accumulation of cells in $S$ occurs sooner for the lower temperature exposure. Before the accum lation of $S$ phase cell starts to be seen, the FMF histogram appears to remain constant. We have termed this interval which occurs prior to the discernible kinetic response, an irterval of general arrest.

Even when the clonogenic survival response to various exposure conditions appears to be constant, the kinetic response nay be different. Figure 16 shows that for cells treated to a $75 \%$ survival level, those treated at $43.0^{\circ} \mathrm{C}$ develop a maximum $S$ region population 6 hours 1 ater than those treated at $42.50^{\circ} \mathrm{C}$. Figure 19 shows that this pattern is consisient when temperatures are extended to include $42.0^{\circ} \mathrm{C}$ and $44.0^{\circ} \mathrm{C}$. The interval between peak $S$ populations increases with decreasing survival (i.e., 12 hours for $25 \%$ survival (Fig. 13) and 15 hours for $2.5 \%$ survival (Fig. 18)).

In summary, the FMF results indicate 1) For a constant temperature the length of the general arrest increases for decreasing survival (Figs. 12 and 13). 2) For iso-survival levels the length of the general arrest increases with increasing exposure temperature (Figs. 16-18). Data from post treatment cell counts indicate delays in cell population growth that supports the FMF resules. 


\section{B. AUTORADIOGRAPHIC STUDIES WITH DNA LABELS}

1. Labeling Index

The labeling index (LI) for ${ }^{3} \mathrm{H} T \mathrm{dR}$ was followed for 36 hours after hyperthermic treatmrnt. Two temperatures $\left(42.5^{\circ} \mathrm{C}\right.$ and $\left.43.0^{\circ} \mathrm{C}\right)$ and 3 survival levels at each temperature $(75 \%, 25 \%$, and $2.5 \%)$ were evaluated. The data indjcated a post treatment kinetic pattern which closely followed the FMF results.

The control LI was $49 \% \pm 1 \%$. Since the LI measures the fraction of cells in $S$, this value is to be compared with a control FMF value of $50 \%$. Figure 20 shows that using $43.0^{\circ} \mathrm{C}$ exposure treatment, peak L.I values occurred 9 hours after treatment at $75 \%$ survival, 12 hours atter trcatmeat for $25 \%$ survival, and 30 hours after treatment for $2.5 \%$ survival. In adititior the LI was lower than control value Eor the earlier time points.

When cells were treated at $42.5^{\circ} \mathrm{C}$, the maximum labeling index value was measured at about 6 hours post treatment for all survival Ievels (Fig. 21). However, a biphasic response was observed for $25 \%$ and $2.5 \%$ survival which can also be seen in the FMF data for these survival levels and exposure temperature.

Iso-survival levels are compared in Figure 22 . Once again, the pattern can be observed that for equal survival response, the time required for the $L I$ to peak incrcases with increasing temperature.

That is, for conditions which yield equivalent clonogenic survival responses, the kinetic response, as measured by autoradiographic labeling index, varies with temperature. On the other hand, for constant temperature, the kinetic response varies with survival level. 


\section{Pulse Labeled Mitoses}

PLi curves for control cells and cells treated at $43.0^{\circ} \mathrm{C}$ tc $75 \%$ and $25 \%$ survival levels are illustrated in Figure 23. For the control population the maximum in the percentage of labeled mitoses occurred 3-1/4 hours after treatment; this period is generally taken to include G2+M. For treated cells this interval lasted $10-1 / 2$ hours for cells treated to $75 \%$ survival and 14 hours for cells to $25 \%$ survival. In the case of treated cells we suggest that this interval represents 62 plus the interval of general arrest referred to earlier in regard to the FMF findings.

The duration of $S$, calculated as the time between the two points on the first wave where $50 \%$ of the rise in labeled mitoses has occurred, was 4-1/2 hours for controls, 5-1/4 hours for cells treated to $75 \%$ survival and $7-1 / 2$ hours for cells trated to $2.5 \%$ survival.

The cycle time for control cells was $12-1 / 2$ hours. This value compares favorably with the population doubling time of $131 / 2$ hours obtained from growth curves. For cells treated to $75 \%$ survival the cell cycle time was $10-1 / 2$ hours, not significantly different from the control value. However, at the $2.5 \%$ survival level, the duration of the first post hyperthermic cell cycle increased to 17 hours. 


\section{DISCUSSION}

\section{SURVIVAL DATA}

The survival data for 94 cells indicate that loss of clonogenic potential occurs for temperatures of $42.0^{\circ} \mathrm{C}$ and higher (Fig. 2). The extent of cell killing is a complex funciion of both the exposure temperature and the exposure time.

In terms of the fraction of cells which survive exposure to hyperthermic conditions, 9L cells appear to be about 4 times more resistant than CHO cells (19) and as much as 60 times more sensitive than pigkidney rells. (61) When compared to Palzer and lieidleberger's data, 9L cells in our hands seem to be more resistant than Hela cells, but the data of Gerner et. 31 . would inficate that $9 \mathrm{~L}$ cells are equally or more sensitive to hyperthermia than Hela cells. (85)

Anoliner measure of cell sensitivity to hyperthermia is the rate at which cells are killed on the exponential region of the survival curve. That is, as the value for $T_{0}$ decreases, sensitivicy increases. In terms of this parameter, 9L cells again appear less sensitive than CHO culls and more sensitive than Hela or pig ikidney cells.

The shape of the hyperthermic survival curve bears a superficial resemblance to radiation survival curves inasmuch as the shoulder and exponential regions are prominent features of both curves. In fact, the parameters of the multitarget radiation model can be used to describe hyperthermic survival curves quite adequately (Table I) (Figs. 3 and 4). However, there are serious problems in the meaningful interpretation of these parameters for hyperthermic survival curves. 
One difficult aspect in the interpretation of hyperthermic survival curves is that time at temperature, or, in other words, rate of cell killing, is not a function of energy transfer into or out of the sulture system. The rate of energy transfer into the system is a function of the temperature difference between the culture system and the water bath according to the formula $l Q=m c t$ where:

$Q$ is energy transferred, in Calories;

$m$ is the mass of the culture system (cells, flask, media, trapped air);

$c$ is the heat capacity of the culture system; and

$t$ is the temperature difference.

Since fo: al temperatures studied, thermal equilibrium at the growing surface of the flask is achieved within 5 minutes of immersing the culture flask into the water bath, the major energy transfer to the culture system is complete within these first few minutes. Since ihe rest of the cxperiment is conducted isothermally, there can be no further net transfer of energy except for that involved in chemical reactions. Yet significant cell killing does not occur until after exposure of 1 hour or more for temperatures up to $44.00 \mathrm{C}$. It is difficult to think of $/ \Omega$ having an effect other than to raise the internal energy of the culture system (according to the first law of thermodynamics $\Delta Q=\Delta U+W$ where $\Delta U$ represents the change in internal energy, and W represents work done). Yet somehow, there is a delay, :n the order of hours, before the critical targets in the cell are affected by the increase in internal energy. 
Thr increase in intornal oresgy due to increased trmpriature most: likely consists of increased kineric energy and increased libelihood of molrorules boing in an activated state. (122) Both thrse factors result in increased rraction urlocitios which have an important effect on collular biocheristry. In jeneral, the spred of a reaction is dembled for rach 10 drgirer rise in temperature. (It is interesting to note that mutation rates also desble for every 10 drgree rise in comperature). The rate of inctease reaction velneity with temperature was theoretically derived by van't Hoif in 1884 (Ref. 59) and is given by

$$
\frac{d\left(\ln k_{i}\right)}{d T}-\frac{\left.d i l n k_{2}\right)}{d T}=\frac{\therefore Q}{2 T^{2}}
$$

where $k_{1}$ and $k_{2}$ are the forward and backward reaction rates respectively, and $T$ is the tomperature, Ricranging the terms yiolds

$$
d\left(\ln \frac{k_{1}}{k_{2}}\right)=\frac{Q d T}{2 T^{2}}
$$

which is nf the sane form as the Arrhenius equation. It is surprising, and may well be significant, that in spite of the complex array of chemical reartions that are in process in a cell, the kinntics of ceil killing by hyperthernia follow the kinetics of the Arrhenius equation (Figs. 4 and 24 ). In fact, $\Delta Q$ in the equation above can be correlated with in the activation energy. Then after integration

$$
\ln (k)=\frac{\mu}{2}\left(\frac{1}{T_{1}}-\frac{1}{T_{2}}\right)
$$

where, for cellular inactivation, $k$ is the net reaction constant and represents the net activation energy for the sum of reactions which 
cause cell death. Conveniently, :. can be calculated from the slope oi the Arthenius curve.

In $1 \mathrm{ight}$ of this Arrhenius :ype anilysis, it is necessary to address two problems. First. since the rraction ratos inirrase as soon as the system rraches thermal oquilibrium (on the rider of minutes), low can the incroased reaction ratrs load to cell death which occurs hours later? And secord, how can the trrhenius analysis, which was developed for specific reactions, be interpreted meaningfully for a cellular systern?

The first question can be answered by considering the effect of increased resction rates on the chrmistry of the cell. Pool sizes for crotain key precursers may begin to eplete. This depletion would not accur instantly, but according to the complicated pathways that surround it. For example, a pathway that builds the pool nav still be intact but the velocity constant for the reaction(s) tilat iruild the pol may not have increased as much as the velocity constant for the renctions that deplete the pool. Alternatively, or in addition, toxins may begin to accumulate at a higher rate than at $37.0^{\circ} \mathrm{C}$. And proteins, nucleotides and memhanes may undergo conformational changes that prevent proper function. There may even be competition within a specific reaction between an incroased reaction constant and decreased availability of the functional molecule due to denaturation. The important point is that the velocity constants for the myrial reactions in the cell may be affected to different extents, resulting in new product concentrations, which may be lethal to the coll, but which could take on the order of hours to achieve. 
The problem of interpreting Arrhenius curves for biological systens has been a subject of controversy for 50 years and tohnson et. al. present a tiorough discussion of the pertinent points. The Crozier theory encompasses most of the important points, as 1 isted below from Johnson's book.

(1) a catenary series of reactions, each with a definite val, temperature characteristic, or critical thermal increment, underlies every physiological process; (2) the overall process is 1 inited, within definite ranges of temperature, by a slowest step or master reaction ( 3 ) at a certain critical temptrature a different master reation may assume control, and a sharp "break" will be apparent in the slopes of lines in an Arrhenius plat of the data; and (4) it might be possible to identify corresponding master reactions in different physiological processes.

The criticisms of Crozier's and similar theories center on the following concepts. First, the designation of which reaction is a mester reaction is arbitrary, since the net results at all temperatures depend on contributory reactions. It may be more accurate to say that some reactions have more influence within a particular temperature range than others.

Second, the accuracy with which a break can be determined on the Arrhenius plot may not be great enough to associate anv specific reaction with the shift in slope. Thus the contributic: made to changes in the slope by differences in temperature characteristics for specific catenary reactions cannot be determined.

Lastly, the assumption that rate 1 imiting reactions may be recrgnized by their measured ן values ignores the extent to which these values may vary as a function of their chemical environment (particularly 
in interspecies comparisons). It may be that the variation in chenical environment cau be largely controlled in cell culture.

in fact, for the cell culture system, the conformity of many cell 1 ines to the Arrhenius relation and the large changes in the slope by a factor of 5 for $9 \mathrm{~L}$ cells supports the assumption that the process of cell death by hyperthermia is predominantly limited by one set of reactions below $43.0^{\circ} \mathrm{C}$ and by another predoininant set of reactions above $43.0^{\circ} \mathrm{C}$.

In addition, the sensitivity of many cell lines can be easily compared if composite Arrhenius grapbs are made. For instance, at a glance, Fig. 24 shows that Chinese hamster iung cells are more sensitive to heat than chinese hamster nuary cells. It is also readily apparent that the entire range of cell inactivation rates for any one temperature lies within a factor of 10 .

Figure 23 shows the change in the shoulder width ( $\mathrm{T}_{\mathrm{q}}$ ) and extrapolation number ( $\mathrm{n}$ ) with temperature. Ben-llur and cn-workers denonstrated that hyperthermia interferes with cellular ability to accumulate sublethal radiation injury $(27,98)$ by reducing the shoulder on the radiation survival curve. And Elkind and whitmore have associated the shoulder region of the radiation survival curve with accumalation of subletha: radiation damage. (103) To date, there has been no such interpretation for the shoulder of hyperthermia survival curves. It seems likely, however, that the shoulder region has some biologicel significance in terms of postponing the lethaity of the hyperthermic insult. 


\section{II . KINFTICS}

Flow microfluorometry (FMF) and autoradiographic techniques were used to study the cell cycle kinetics when cells were returned to $37.00 \mathrm{C}$ after treatment. The FMF data presented in Fig. 19 show a clear difference in the call cycle progression of 91 celis treated at $42.0^{\circ} \mathrm{C}, 42.5{ }^{\circ} \mathrm{C}, 43.0^{\circ} \mathrm{C}$ or $44.0^{\circ} \mathrm{C}$ although the fraction of surviving cells were chosen to be the same. Initially, cell progression through the cell cycie appeared to be stopped at all points in the rell cycle. This interval which we termed "general arrest", was followed by an accumulation of ce? $1 \mathrm{~s}$ in $S$. We suspect that at the end of the general arrest, released cells piogressed through the cell cycle until they reached a block in 5 which had not yet been released, zausing cells to accumulate. The block in $S$ took four times as long to appear at $44.0^{\circ} \mathrm{C}$ thiall at $42.50^{\circ} \mathrm{C}$. When treated at $43.0^{\circ} \mathrm{C}$ the $\mathrm{s}$ phasio bucic took 3 times as long to develop as when cells were treated at $42.5^{\circ} \mathrm{C}$. Figures 16-19 show that the length of the general arrest increases with increasing temperature for constant surviving fractions. Figures 2 and 13 show that the general arrest also increases with decreasing survival achieved by use of a single temperature. The lower survival levels, however, do not appear to rcpresent a selected population of non-growing cells, ince the kinetics for a particular survival level, say, $2.5 \%$ survival level differ significantly depending on the temperature used. In fact, the duration of the general arrest for cells treated to $2.5 \%$ survival at $42.5^{\circ} \mathrm{C}$ is about equivalent to cells treated at $43.0^{\circ} \mathrm{C}$ to $75 \%$ survival. 
Thus the length of the general arrest may constitute a more sensitive index of physiologic stress to the cell than simple reproductive mortality. The exact nature of the stress is open to speculation at this point. Some possibilities include, ".pletion of important precursors due to altered rate kinetics or due to membranes which have become leaky, heat inactivation of key enz,mes or other macromolecules, or acceleration of non-essencial or damaging chemical reactions which compete with necessary reactions. The introruction of thernal noise which could interfere dith the stereo sper sicity of key biochemical events is not likely to be important for the 6 centigrajo degree temperature shift considered in this research.

Following the relcase of tbe $S$ phase block at 9 hours post treatment, the accumlated coinort of cells cntered the G2+M phase. This is indicated for $43.0^{\circ} \mathrm{C}, 75 \%$ survival condition, in Fig. 11. It appears that the cells which had previously been in $G 2+M$ have also been released and have moved into $G l$ as indicated by the gradual increase in the percent cells in Gl beginning at 9 hours. This time correlates well with the time when the number of cells starts to increase (9-12 hours post treatment) (Fig. 14).

The pattern of an $S$ phase block followed by progression to $\mathrm{C2}+\mathrm{M}$ and $G l$ as a resul: of nyperthermic treatment has been observed for ather cell lines. $(67,69,70)$ We observed this same qualitative pattern for each exposure condition. The major qualitative difference we observed was in the length of the general arrest which varied quantitatively with exposure condition. The kinetics of cell redistribution 
in the cell cycle may be clinically important in designing mixed modality treatment schedules.

The labeling index (LI), measured by autoradiography, of cells trosted identically to those used for the F IF studies revealed almost the same pattern of post treatment kinetics for cells in S. At $25 \%$ survival it took 3 to 't times as long for the $S$ phase cell accumulation to develop when $43.0^{\circ} \mathrm{C}$ was used rather than when $42.5^{\circ} \mathrm{C}$ was used. That is, the general arrest increased with increasing temperatures, for iso-survival levels. At $43.0^{\circ} \mathrm{C}$, the general arrest increased w'th decreasing survival level. In addition, the LI was considerably below control values during the time of the general arrest. This data suggests that the cells have actually stopped incorporating thymidine during the interval of the general arrest. This could be due to the same reasons speculated on above, during the discussion oi the FiF data.

The LI data for cells trcated at $42.5^{\circ} \mathrm{C}$ also shows reduced numbers of cells incorporating thymidine during the time of the general arrest. The constant duration of the general arrest, as indicated by a maximum incorporation of tritiated thymidine occurring at 6 nours post treatment for all survival levels, may be associated with the location of this temperaturt on the initial portion of the Arrhenius plot. The mechanism of recovery from the general arrest may be different. The biphasic response seen at $42.5^{\circ} \mathrm{C}$ but not at $43.0^{\circ} \mathrm{C}$ also indicates a different dominant mechanism. Or the explanation may merely be that, at $42.50^{\circ}$ the differencs in duration of the general arrest is less than three hours, while we took measurements at 3 hour intervals. The biphasic 
response at $75 \%$ survival fur $42.50 \mathrm{C}$ may have been suppressed by the increase in cell numbers which occurs sooner for this exposure condition. The pulse labeled mitoses (PLM) curves illustrated in Fig. 23 further confirm the existence of a state of general arrest which increases in duration as the severity of exposure increases. The interval between the end of the pulse and the first peak of labelled mitoses is usually taken to represent the $G 2+M$ phase of the cell cycle. However, with treated cells, the increase in this interval may be caused by the period of general arresc combined with the period of G2+M. Such a supposition is supported by the fact that the pattern of lengthening of the $G 2+M$ interval as measured in the PLM curves follows the pattern of lengthening of the general arrest as measured by FMF (Fig. 11) and LI (Fig. 21). That is, the general arrest increases with increasing severity of treatment.

It should be noced that the peak of the PIM curve, even in the case of the control, does not reach $100 \%$ labeled mitoses. We cannot completely explain this fact; however, we can speculate on a tew contributing factors. First, there may be a variance in the cell cycle time among cells, since they are classified as a mixed glicsarcoma. There may be a subpopulation of cells in $\mathrm{G} 2+\mathrm{M}$ which are slowly rel-ased. In addition we counced both prophase and metaphase cells as mitotic which tends to yield a hroader and lower peak than if only labeled metaphase are counted. However, the shape of the curves is difinite enough to extract extensive information on the parameters of the cell cycle. The fact that the peaks are lower for experimental conditions than for control conditions may indicate that some cells die in mitoses 
during treatment but continue to be observed as unlabeled mitotic cells for the duration of the observation perind.

The control cell cycle period of $121 / 2$ hours is consistent with the population doubling time of $131 / 2$ hours. The population doubling time is longer due to some cell death than would be expected in colony growth. It is also expected that the duration of $S$ will be shorter when calculated from the PLM curve than when calculated from the FMF histogram. This is because the FMF histogram includes all cells which have a DNA content corresponding to S region cells while the LI and PlM curves count only that subpopulation which is actively taking up thymidine at $z$ great enough rate 7 the time of the pulse to see on the autoradjographs. Thus a cell with DNA content corresponding to $S$ phase cells but which is not taking up thymidine at the time of the pulse will be counted as $S$ by FMF but not by PLM analysis. For the $2.5 \%$ survival conditions the PLM curve indicated a lengthening of the cycle period by approximateiy $40 \%$, along with a concomitant increase in the duration of $S$. It appears that the cells continue to grow appriximately $40 \%$ more slowly than control cells even after the general arrest has terminated. The mitoses which occur at about 18 hours to not correlate with an increase in cell population as shown in Fig. 14. It is possible that at this stage drad cells begin to lyse at about the same rate that new cells are generated. At $75 \%$ survival the first mitotic peak correlates well with an increase in coll counts indicated in Fig. 11 .

We have shown that 9L cells exhibit thermal tolerance (as evidenced by a 2 to 6 fold increase in $T_{0}$ ) when treated with a split exposure 
to $43.00^{\circ}$ temperatures. Thermal tolerance does not appear to be caused by redistribution of cells within the cell cycle in response to the initial hyperthermic treatment. First of all, our data shows that cells cease to progress during a general arrest period which, at most survival levels observed, is greater than the three hours that cells are allowed to spend at $37.0^{\circ} \mathrm{C}$ between treatments. Thus redistribution could not occur during this time. Secondly, when cells do begin to progress, they tènd to accumulate in the $S$ phase, which has been reported to be the most sensicive phase of the cell cycle to heat $(19,55)$ and so would not be expected to exhibit resistant qualities. Studying other aspects of cell kinetics and thermal tolerance, Sapareto has also arrived at these conclusions.

Treatment schedules which are similar to those used here have been reported to produce thermal tolerance in other cell lines. $(2,69,85,87)$ Leith (2) has suggested that thermal tolerance (TT), defined as the ratio of the resistant mortality rate to the single exposure mortality rate, may be dependent mainiy on survival level resulting from the initial exposure, with the thermal tolerance increasing as the initial survival level decreases. Figure 8 illustrates the extent to which $9 \mathrm{~L}$ data matches other data Leith has plotted. (2) Although it is difficult to say whether the increase in TT is significant for 9L cells, it is suggestive that for initial survivals of $25 \%, 5 \%$, and $1 \%$ treated at $43.0^{\circ} \mathrm{C}$, the $9 \mathrm{~L}$ data fits directly on the log-1inear plot which represents thermal tolerance of Hela and CHO cells. At $75 \%$ survival the $9 \mathrm{~L}$ data is outside the range initially considered in Leith's analysis and the thermal tolerance ratio sits considerably 
off the line that the other points form. This variation may have a physiological basis in the fact that it is the only initial survival level taken well on the shoulder of a single exposure survival curve. On the other hand, the thermal tolerance ratio resulting from $1 \%$ initial survival level falls directly on the line formed by Hela and cho cells thus pxtanding the range of the $10 \mathrm{~g}-1$ iner relationship between $\mathrm{S}_{i}$ and $\mathrm{rT}$. 


\section{ACKNOWLEDGMENTS}

I gratefully acknowledge the invaluable assistance of three people who supported me both intellectually and scientifically during the course of the work presented herein. In chronological order in which I met them they are: Cornelius Tobias, whose stimulating ideas kept me perpetually interested. John T. Leith, who initially suggested the topic of hyperthermia and whose comments have been continually helpful. Edward L. Alpen, my research advisor, whose guidance turned the trials and tribulations of research into an enjoyable learning experience and who was always ready to discuss ani consider new ideas. This work was done under the auspices of the U. S. Department of Energy. 


\section{REFERENCES}

1. G. Moricca, et al., "Hyperthermic Treatment of Tumours: Experimental and Clinical Applications," Recent Results Cancer Res. 59, 112$152(1977)$.

2. J. T. Leith, et al., "Hyperthermic Potentiation: Biological Asprets and Applications to Radiation Therapy, " Cancer 39(2), 766-779 (Feb 1977).

3. R. C. Miller, et al., "Prospects for Hyperthermia in Human Cancer Therapy. Part I: Hyperthermic Effects in Man and Spontaneous Animal T smors," Radiology 123(2), 489-495 (May 1977).

4. Committee for Radiation Oncology Studies, "Hyperthermia in the Treatment of the Canrer Patient," Cancer 37(4), 2075-2083 (Apt Supplement 1976).

5. W. Busch, "Uber den Einfluss, Welchen Heftigere Erysipeln Zuweilen auf Organisierte Neubildungen Ausuber," Vertandl. Naturh. Preuss. Rhein. Westphal. 23, 28-30(1866).

6. G. L. Rohdenberg, "Fluctuations in the Growth of Malignant Tumours in Man, with Special Reference to Spontaneous Recession," J. Cancer Res. 3, 193-225 (1918).

7. S. L. Warren, "Preliminary Study of the Effect of Artificial Fever Upon Hopeless Tumor Cases," Am. J. Roentgenol. 33, 75-87 (1935).

8. R. T. Pettigrew, et al., "Whole-body Hyperthermia. A Systemic Treatment For Disseminated Cancer," Recent Results Cancer Res. 59, $153-170(1977)$. 
9. R. T. Pettigrew, "Cancer Therapy by Whole Body Heating," in Intern. Symp. on Cancer Therapy by Hyperthermia and Radiation (Washington, D.C., Apzil 28-30, 1975).

10. R. Cavaliere, "Regional Hyperthermia by Perfusion," in Intern. Symp. on Cancer Therapy by Hyperthermia anj Radiation (Washington, D.C., Apri1 28-30, 1975).

11. R. Cavaiere, E. C. Ciocatto, et al., "Selective Heat Sensitivity of Cancer Cells," Cancer 20, 1351-1381 (1967).

12. W. G. Connor, et al., "Prospects for Hyperthermia in Human Cancer Therapy. Part II: Implirations of Biological and Physical Data for Applications of Hyperthermia to Man," Radiology 123(2), 497-503 (May 1977).

13. B. C. Ciovanella, "Actions of Hyperthermia on Tumor Cells Cultured in Vitro," Recent Results Cancer Res. 59, 36-42 (1977).

14. R. Strom, et 21 ., "Biochemical Aspects of Heat Sensitivity of Tumor Cells," Recent Results Cancer Res. 59, 7-35 (1977).

15. J. A. Dickson, "The Effects of Hyperthermia in Animal Tumour Systems," Recent Results Cancer Res. 59, 43-111 (1977).

16. B. C. Giovanella, et al., "Selective Heat Sensitivity of Cancer Cel1s: Introduction," Recent Results Cancer Res. 59, 1-6 (1977).

17. H. D. Suit, "Hyperthermic Effects on Animal Tissues," Radiology $123(2), 483-487$ (May 1977).

18. H. D. Suit, H. Schwayder, "Hyperthermia: Potential as an AntiTurnor Agent," Cancer (Philad.) 34, 122-129 (1974).

19. W. C. Dewey, et al., "Cellular Responses to Combination:s of Hyperthermia and Radiation," Rádiology 123(2), 463-474 (May 1977). 
20. I. Harisladis, et al., "Thermal Tolerance and Repair of Thrornal Damape by Cultured Colls," Radiology 12,(2), 505-509 (May 1977).

21. J. Overgatd, ot al., "The Influrnec of Hypoxia and Acidity on the Hyperthrermic Response of Malignant Colls in Vitro," Radiolngy $123(2), 511-514(\mathrm{May} ! 977)$.

22. D. F. Thrall, et a1., "Rosponses of Cells in Vitso and Tissuss in Vivo to Hyperthormia and X-Irradiation," in Advanres in Radiat. Biol., J. iett., Fd. (Acadrmic Press, NY, 1976) 6, 211-226.

23. I. Har-Kedar and N. M. Blrechen, "Feperimental and Cilinien! Aspects of Hyprethermin Applied to the Treatment of Caneor with Sprorial Reference to the Role of Ultrasonic and Microwave linating," in Adv. in Radist. Riol., J. Intt., Ed. (Acadomic Pross, NY, 1976) 6. $229-266$.

24. R. V. Bronk, "Thermal Potentiation of Mammalian Cell Killing: Clues for Understanding ano Potential for Tumor Therapy," in Adv. in Radiat. Biol. J. Lett., Ed. (Academic Press, NY, 1976) 6. $267-324$.

25. T. T. Chen and C. lieidelberger, "Quantitative Studies on the Malignant Transformation of Mouse Prostate Cells by Carcinogenic Hydrocarbons in vitro," Int. J. Cancer 4 , 166-178 (1969).

26. J. A. Belli and F. J. Bonte, "Influence of Temperature on the Radiation Response of Mammalian Cells in Tissue Culture," Radiat. Res. 18, 272-276 (March 1963). 
27. E. Ben-hur, M. M. Elkind, and B. V. Bronk, "Thermally Enhancest Radio-Response of Cultured Chinese Hanster Cells: Inhibition of Repair of Sublethal Damage and Enhanceraent of Lethal Danas:", Radiat. Res. 58, 38-51 (Apri1 1974).

28. G. M. Mahn, "Metalolic Aspects of the Role of Hyperthermia in Kanmalian Coll Inactivation and Theit Pastible Relevance to Canret Treatment," Cancer Rrs. 34, 3117-3123 (November 1974).

29. G. M. Hahn, J. Braın, ard I. Har-Kedar, "Mhermochemetherapy: Syarespism Brtwren Hyprertibremia (42-430) and Adriamycin (or Blmomyrin) in Mammalian Cell Inactivation," Prnc. Natl. Acad. Sci. USA 72 , $937-940$ (March 1975$)$.

30. R. A. Lambert, "Demonstration of the Creater Susceptability to Hoat of Sarcoma Cells," IAMA 59. 2147-2148 (1912).

31. K. Ovrrgaard and J. Overgaard, "Investigations on the Possibility of a Thermic Tumor Therapy--I," Eur. J. Cancer 8, 65-78 (1972).

32. J. Ovirgard, "Influence of Extracellular pH on the Viability and Morpholngy of Tumor Cells Exposed to Hyperthermia," J. Natl. Sancer Inst. 56, 1243-1250(1976).

33. L. E. Gerweck and E. Rottinget, "Enhancement of Marnmalian Cell Sensitivity to Hyperthermia by pHa Alteration," Radiat. Res. 67, $508-511(1976)$.

34. L. E. Gerweck, "Modification of Ce1! Lethality at Elevated Temperatures. The pH Fffect," Radiat. Res. 70, 224-235 (1977).

35. B. C. Giovanella, et al., "Selective Lethal Effect of Supranormal Temperatures on Mouse Sarcoma Ce11s," Cancer Res. 33, 2568-2578 (November 1973). 
36. B. Mondovi', R. Strom, G. Rotilio, A. Finazzi-Agro', R. Cavaliere, and A. Rossi-Fanelli, "The Biochemical Mechanism of Selective Heat Sensitivity of Cancer Cells. I. Studies on Cellular Respiration," Eur. J. Cancer 5, 1.29-136 (1969).

37. B. Modovi', A. Finazzi-Agro', G. Rotilió, R. Strom, G. Moricca, and A. Rossi-Fanelli, "The Tiochemical Mechanism of Sclective Heat Sensitivity of Cancer Cells. HI. Studies on Nucleic Acids and Protein Synthesis," Eur. J. Cancer 2, 137-146 (1969).

38. C. Turano, A. Ferraro, R. Strom, R. Cavaliere, and A. Rossi-Fanelli, The Biochemical Mechanism of Selective Heat Sensitivity of Cancer Cel1s. I1t. Studies on Lysosomes," Eur. J. Cancer 6, 67-72. (1970).

39. R. Strom, A. S. Santoro, C. C. A. Hozzi, et al., "The Biociemical Mechanism of Selective Heat Sensitivity of Cancer Cells. IV. Inhibition of RNA Synthesis," Eur. J. Cancer 9, 103-112 (1973).

40. Z. F. Kachani and A. B. Sabin, "Reproductive Capacity and Viability at Iigher Temperatures of Various Transformed Hamster Cell Lines," J. Nat 1. Cancer Inst. 43, 469-480 (1969).

41. J. A. Power and J. W. Harris, "Response of Extremely Hypoxic Cells to Hyperthermia: Survival and Oxygen Enhancement Ratios,"

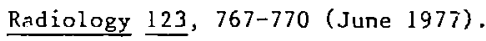

42. L. Harisiadis, E. J. Hall, U. Karljevic, et al., "Hyperthermia: Biological Studies at the Cellular Level," Radiology 117, 447-452 (November 1975).

43. S. H. Kim, J. H. Kim, and E. W. Hahn, "Enhanced Killing of Hypoxic Tumor Cells by Hyperthermia," Radiology 114, 727-728 (March 1975). 
44. L. E. Gerweck, E. L. Gillette, and W. C. Dewey, "Killing of Chinese Hamster Cells in Vitro by Heating Under Hypoxic or Aerobic Conditions," Eur. J. Cancer 10, 691-693 (1974).

45. E. W. Gernet, V. G. Connor, M. L. M. Boone, et a1., "The Potential of Localized Healing as an Adjunct to Radialion Therapy, "Radiology $115,433-439$ (August 1975).

46. J. E. Robinson, M. J. Wisenberg, and W. A. McCready, "Radiation and Hyperthermal Response of Normal Tissue in Situ," Radiology 113, 95-198 (October 1974).

47. N. Schulman and E. J. Hal1, "Hyperthermia: Its Effeci on Proliferative and Plateau Phase Cell Cultures," Radiology 113, 209-211 (October 9974).

48. D. E. Thral1, E. 1. Gillett, and W. C. Dewey, "Effect of Heat and Ionizing Radiation on Normal and Neoplastic Tissue of the C3H Mouse," Radiat. Res. 63, 363-377 (August 1975).

49. G. M. Bahn, "Thermochemotherapy: Interactions between Hyper thermia and Chemotherapeutic Agents," in Proceedings of the International Symposium on Cancer Therapy by Hyperthermia and Radiation (Washington, 1975).

50. J. E. Robinson and $M$. J. Wizenberg, "Thermal Sensitivity and the Effect of Elevated Temperatures on the Radiation Sensitivity of Chinese Hamster Cells," Acta Radiol. 13, 241-248 (1974).

51. L. E. Gerweck, E. L. Gillette, and W. C. Dewey, "Effect of Heat and Radiation of Synchroncus Chinese Hamster Cells; Killing and Repair," Radiat. Res. 64, 611-623 (1975). 
52. S. H. Kin, J. H. Kim, and E. W. Hahn, "The Enchanced Killing of Irradiated HeLa Cells in Synchronous Culture by Hyperthermia," Radiat. Res. 66, 337-346 (1976).

53. P. Ross-Riveros and J. T. Leich, "Response of 9L Timor Cells to Hyperthermia and $X$-lrradiation," Radiat. Res. (in press).

54. G. C. Li and B. K. Herdrik, "Effect of Hyperthermia on the Radiation Response of Two Matnmalian Cel1 Lines," Eur. J. Cancer 13, 65-69 (1977).

55. A. Westra and $W$. C. Dewey, "Variation in Sensitivity to lleat Shock During the Cell-Cycle of Chinese Hamster Cells in Vitro," Intern. J. Radiat. Biol. 19, 467-477(1971).

56. E. W. Gerner and J. T. Leith, "Interaction of Hyperthermia with Radiations of Different Linear Energy Transfer," Intern. J. Radiat. Biol. $31(3) 283-288(1977)$.

57. R. J. Palzer and C. Heidelberger, "Studies on the Quantitative Biology of Hyperthermic Killing of HeLa Cells," Cancer Res. 33 , 415-421(i973).

58. R. J. Palzer and C. Heidelberg, "Influence of Drugs and Synchrony on the Hyperthermic Killing of Hela Cells," Cancer Res 33, 422$427(1973)$.

59. F. H. Johnson, H. Eyring, and M. J. Palissar, The Kinetic Basis If Molecular Bjology (John Wiley and Sons, NY, 1954), pp. 2-5, $197-285$.

60. K. Kase and G. M. Hahn, "Differential Heat Response of Normal and Transformed Human Gells in Tissue Culture," Nature 255, 228230 (May 1975). 
61. M. Harris, "Temperature-Resistant Variants in Clonal Population of Pig Kidney Cells," Exp. Cell Res. 46, 301-314 (1967).

62. E. M. Levine and E. B. Robbins, "Dif F̂erential Temperature Sensitivity of Normal and Cancer Cells in Culture," J. Cell Physiol. 76, 373-379 (December 1970).

63. B. C. Giovanella, W. A. Lohman, and C. Heidelberger, "Effects of Elevated Temperatures and Drugs on the Viatility of L1210 Leukemia Cells," Cancer Res - 30, 1623-1631 (1969).

64. C. R. Reeves, "Mechanisms of Acquired Resistance to Acute Heat Shock in Cultured Mammalian Cells," J. Ce1l Physiol. 79, 157-170 (1972).

65. J.A. Dickson and D. M. Shah, "The Effect of Hyperthermia on the Biochemistry and Growth of a Malignant Gell Line," Eur. J. Cancer 8, 561-571 (October 1972).

66. D. N. Rao and J. Engelberg, "Effects of Temperature on the Mitotic Cycle of Normal and Synchronized Mammaliar Cells," in Coll Synchrony, I. L. Cameron, and G. M. Padilla, Eds. (Academic Press, NY, 1966), Pp. 332-353.

67. H. B. Kal, M. Hatfield, and G. M. Hahn, "Cell Cycle Progression After X-Irradiation or Heat Shock," Radiology 117, 215-217 (October 1975).

68. H. B. Kal and G. M. Hahn, "Kinetic Responses of Murine Sarcoma Cells to Radiation and Hyperthermia in Vivo and in Vitro," Cancer Res. 36, 1923-1929(1976). 
69. S. A. Sapareto, L. E. Hopwood, W. C. Dewey, M.R. Raju, and J. W, Gray, "Effects of llyperthermia on Survival and Progrossion of CHO Cells," Cancer 38, 393-400(1978).

70. H. Schlag and C. lucke-Huhle, "Cytokinetic Studies on the Ferfect of Hypertherinia un Chimese Biamster Lung Ce11s," Eur. J. Cancer 12, $827-831(1976)$.

71. C. Lucke-tuhle and H. Dertinger, "Kinetic Response of an in Vitro "Tumour-Model" (V79 Spheroids) to 429 C Hyperthermia," Eur. J. Cancer 13(1), 23-28 (January 1977).

72. S. Lrwin and D. S. Pepper, "Variztion of the Melting Trmparature oE Callthymus DNA with $\mathrm{pH}$ and Type of Buffer," Atch. Biochem. Biophys. 109, 192-194 (January 1965).

73. J. Matmur, "Thermal Denaturation of Deoxyribnsenucleic Acid Isolated from a Thermophile," Biochim. Biophys. Acta 38, 342-343 (1960).

74. T. N. Evreinova, I. M. Davydova, A. P. Sukover, and S. V. Goryunova, "Nucleic Acids of Thermophilic Blue-Green Algá Mastigocladus Liminosus," Dokl. Akac. Nauk. USSR 137, 213-215 (1961). (English transi.: Doklady, Biochem. Sect. 137, 43-46).

75. J. Dvergard, "Ultrastructure of a Murine Mammary Carcinoma Exposed to Hyperthermia in Vivo," Cencer Res. 36, 983-995 (1976).

76. R. Warocquire and R. Scherrer, "RNA-Metabolism in Mammalian Cells Elevated Temperature," Eur J. Biochern. I0, 362-370(1969).

77. A. B. Novikoff and E. Holtzman, Cells and Organelles (Holt, Rinehart and Winston, NY, 1970). 
78. S. J. Singer, "Membrane Flu:dity and Cellular Functions," in Adv. Exp. Med. and Biol. 62, R. H. Meints and E. Davies, Eds. (Plenum Press, NY, 1975), PP. 181-191.

79. C. D. Linden, K. L. Wright, H. M. McConnel, and C. F. Fox, "Latera1 Phase Separations in Membrane Lipids and the Mechanism of Sugar Transport in Escherichia Coli," Proc. Nat1. Azad. Sci. 1SSA 70, 2271-2275 (August 1973).

80. P. Overath and h. Trauble, "Phase Transitions in Cells, Membranes, and Lipids of Escherichia Coil," Biochemistry 12, 2625-2634 (July 1973).

81. A, G. Lee, "Functional Properties of Biological Membranes: A Physical Chemical Approach," Prog. in Biophys. and Mol. Biol. 29, 3-56 (1975).

82. R. J, Palzer, University of Crilifornia, Eerkeley, California, private communication (February 1978).

83. J. L. Marx, "Biochemistry of Cancer Cells: Focus on the Cell Surface," Science 183, 1279-1282 (March 1974).

84. D. Chapman, "Phase Transitions and FIuidity Characteristics of Lipids and Cel1 Membranes," Q. Rev. of Biophys. 8, 185-235 (1975).

85. E. W. Gerner, R. Boone, W. G. Connor, J. A. Hicks, and M. L. M. Boone, "A Transient Thermotolerant Survival Response Produced by Single Thermal Tolerant Doses in HeLa Cells," Cancer Res. 36, $1035-1040(1976)$.

86. E. W. Gerner and M. J. Schneider, "Induced Thermal Resistance in Hela Cells," Nature 256, 500-502 (1975). 
87. K. J. Henle and D. B. Leeper, "Interaction of Hyperthermia and Rediation in CHO Cells: Recovery Kinetics," Radiat, Res. 66, $505-518(1976)$

88. B. G. Gaffney and D. C. Lin, "Spin-Label Measurements of Membranebound Enzymes," The Enzymes of Biological Membranes, Antony Martinosi, Ed. (Plenum Press, NY, 1976), Vol. 1, PP. 77-82.

89. R. D. Mavis, "Membranous Fnaymes as Probes of Lipid-protein Interactions," The Enzymes of Biological Membranes, Antony Martinosi, Ed. (Plenum Press, NY, 1976), Vol. 1, pp. 201-206.

90. R. J. DeHoratius, J. M. Hosea, D. E. Van Epps, W. P. Reed, W. S. Edwards, and R. C. Williaris, Jr., "Immunologic Function in Humans Before and Afcer Hyperthermia and Chemotherapy for Disseminated Mal ignancy," J. Nat l. Cancer Inst. 58(4), 905-911 (1977).

91. B. Mondovi', A. S. Santoro, R. Strom, R. Faiula; and A. RossiAcid Composition of Moderately and Extremely Thermophilic Bacteria," Lipids $\underline{9}(7), 476-480(1974)$.

93. M. B. Yatvin, "The Intluence of Membrane Lipid Composition and Procaine on Hyperthermic Death of Cells," Int. J. Radiat. Biol. $\underline{32}(6), 513-521(1977)$.

94. M. Ehrstrom, L. E. G. Eriksson, J. Israelachvili, and A. Ehrenberg, "The Fffects of Some Cations and Anions on Spin Jabelled Cytoplasmic Membranes of Bacillus Sublilis," Bioch. Biophys. Res. Comm. 55(2), $396-402(1973)$.

95. J. R. Hazel and C. L. Prosser, "Molecular Mechanisms of Temperature Compensation in Piokilotherms," Phyjial. Rev. 54, $620-677(1974)$ 
96. S. K. Komatsu and R. E. Feeney, "A Heat Labile Fructose-diphosphate Aldolase from Cold Adapted Antarctic Fishes," Biochim, Biophys. Acta 206, 305-315 (1970).

97. B. Usakov, "Thermistability of Cells and Proteins in Poikilotherms," Physial. Rev. 44, 518-560 (1964).

98. E. Ben-Hur and M. M. Elkind, "DNA Damage and its Repair in Hyperthermic Mammelian Cells: Relation to Enlaanced Cell Killing," in Radiation Research, 0. Nygaard, et al., Eds. (1ntern. Congress cf Radiation Research, 5th, Seattle, 1974) (Academic Press, NY, 1975) .

99. E. Ben-Hur and M. M. Elkind, "Thermally Enhanced Radioresponse of Cultured Chinese Hamster Cells: Damage and Repair of SingleStranded DNA and a DNA Complex," Radiat. Res, 59, 484-495 (1974).

100. E. Ben-Hur, "Mechanisms of the Synergistic Interaction Between Hyperthermia and Radiation in Culcured Mammalian Cells," J. Radiat. Res. $17,92-98$ (1976).

101. E. Ben-Hur, B. V. Bronk, and M. M. Elkind; "Thermally Enhanced Radio-sensitivity of Cultured Chinese Hamster Cells," Nature (New Biology) 238, 209-211 (1972).

102. P. M. Corry, S. Robinson, and S. Cetz, "Hyperthermic Effects on DNA Repair Mechanisms," Radiology 123, 475-482 (May 1977).

103. M. M. Elkind and G. F. Whitmore, The Radiobiology of Cultured Mammalian Cells," (Gordon and Breach, NY, 1967).

104. M. M. Elkind and H. Sutton, "Radiation Response of Mammalian Cells Grown in Culture. I. Repair of X-Ray Damage in Surviving Chinese Hamster Cells," Radiat. Res. 13, 556-593 (1960). 
105. E. W. Gerner, University of Arizona College of Medicine, Tucson, Arizona, private communication (1976).

106. E. W. Gerner and D. H. Fusse11, "The Relationship Between Polyamine Accumulation and DNA Replication in Synchranous Chinese Hamster Ovary Cells After Heat Shock," Cancer Res. 37, 482-489 (February 1977).

107. G. Hahn, Stanford University School of Medicine, Stanford, Californa, private communication (1978).

108. D. Deen, University of California Medical School, San Francisco, California, private communication (1977).

109. M. D. Walker and E. A. Gehan, "Clinical Studies in Malignant G1iomas and their Trealment with the Nitrosureas," Cancer Treat. Rep. 60 (6), 713-716 (June 1976).

110. D. Zakim and D. A. Vessey, "The Effects of Lipid-Protein Interactions on the Kinetic Parameters of Microsomal UDP-glururonyltransferase," Tine Enzymes of Eiological Membranes, Antony Martinosi, Ed. (Plenum Piess, NY, 1976) Vo1. 2, Pp. 455-458.

111. H. A. Crissman, M. M. Oka, and J. A. Steinkamp, "Rapid Staining Methods for Analysis of Deaxyribonucleic Acid Protein in Mammalian Ce11s," J. Histachem. Cytochem. 24, 64-71 (1976).

112. J. A. Steinkamp, M. J. Fulwyler, J. R. Coulter, R. D. Hicbert, J. L. Horney, and P. F. Mullaney, "A New Multiparameter Separater For Microscopic Particles and Biological Cells," Rev. Sci. Inst. 44, 1301-1310 (1973).

113. D. M. Holm and L. S. Cram, "An Improved Flow Microfluorometur for Rapid Measurement of Cell F1uorescence," Exp. Ce11 Fies. 80, $105-110(1973)$. 
114. K. Nomura, T. Hoshino, K. Knebel, and M. Barker, "BCNU-Induced Perturbations in the Cell cycle of gl Rat Brain Tumor Cells," Cancer Treat. Rep. 62(5), (unpublished).

115. M. Harris, "Criteria of Viability in Heat-Treated Cel1s, "Exp. CE11 Res. 44, 658-661 (1966).

116. H. H. Schmidek, et al., "Morphological Studies of Rat Brain Tumors Induced by N-nitrosomethylurea," J. Neurosurg. 34, 335340 (March 1971).

117. G. Hahn, Stanford University School of Medicine, Stanford, California, private communication (1976).

118. C. Lucke-Hule, Institute fur Strahlenbiologie, Federal Republic of Gemany, private communication (1977).

119. D. C. Ward, E. Reich, and I. H. Goldberg, "Base Specificity in the Interaction of Polynucleotides with Antibiotic Drugs," Science $149,1259-1263$ (1965).

120. M. Waring, "Variation of the Supercoils in Closed Circular DNA by Binding of Antibiotics and Drugs: Evidence for Molecular Models Involving Intercalation," J. Mol. Biol. 54, 247-279 (1970).

121. B. Hudson, W. B. Upholt, J. Devinny, and J. Vinograd, "The Use of an Ethidium Bromide Analogue in the Dye-buoyant Density Procedure for the Isolation of Closed Circular DNA: The Variation of the Superhelix Density of Mitochondrial DNA," Proc. Nat1. Acad. Sci. USA 62, 813-820 (1969). 
122. H. D. Crockford and S. B. Knight, Eundamentais of Physical Chemistry (John Wiley \& Sons, New York, 1964), 2nd Ed.

123. Webster's New Universal Dictionary of the English Language (Webster's Universal Press, NY, 1977). 
SURVIVAL CURVE PARAMETERS

\begin{tabular}{|c|c|c|c|c|}
\hline $\begin{array}{l}\text { Temperature } \\
\text { (measired) } \\
{ }^{\circ} \mathrm{C}\end{array}$ & $\begin{array}{c}\text { Slope, } k,(95 \% \text { Confidence) } \\
\text { calculated by method } \\
\text { of least squares } \\
\text { min. }-1\left(\times 10^{-3}\right)\end{array}$ & $\begin{array}{c}T_{0} \\
\text { calculated } \\
T_{O}=1 / \mathrm{k} \\
\min .\end{array}$ & $\begin{array}{c}n \\
\text { calculated } \\
\text { for least } \\
\text { square fit } \\
\end{array}$ & $\begin{array}{c}\mathrm{T}_{\mathrm{Q}} \\
\mathrm{T}_{\mathrm{Q}}^{\text {calculated }}=\underset{\mathrm{min}}{=} \ln \mathrm{n}\end{array}$ \\
\hline 42.0 & $-3.13 \pm 0.11$ & 320 & 1.1 & 16 \\
\hline 42.5 & $-20.5 \pm 3.8$ & 49 & 14 & 130 \\
\hline 43.0 & $-59.5 \pm 15.4$ & 17 & 91 & 76 \\
\hline 44.0 & $-107 \pm 71$ & 9.3 & 35 & 33.0 \\
\hline 45.0 & $-178 \pm 71$ & 5.6 & 8.6 & 12 \\
\hline
\end{tabular}


$71 a$

\section{TABLE II}

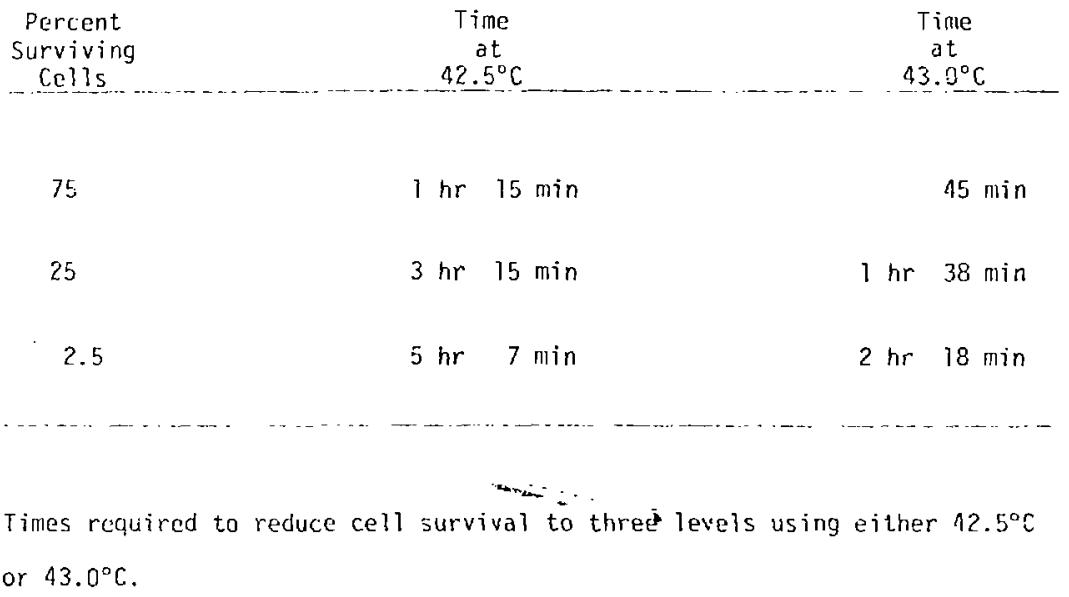




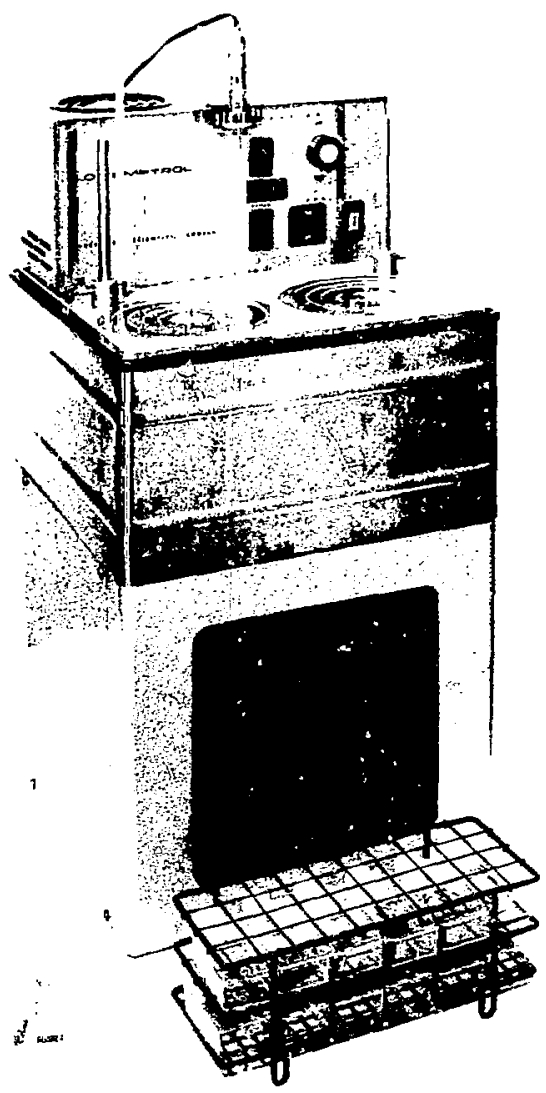

(:313 765-432S

Plate 1. Water bath with culturc flasks arranged on test tube rack for inmersion. 


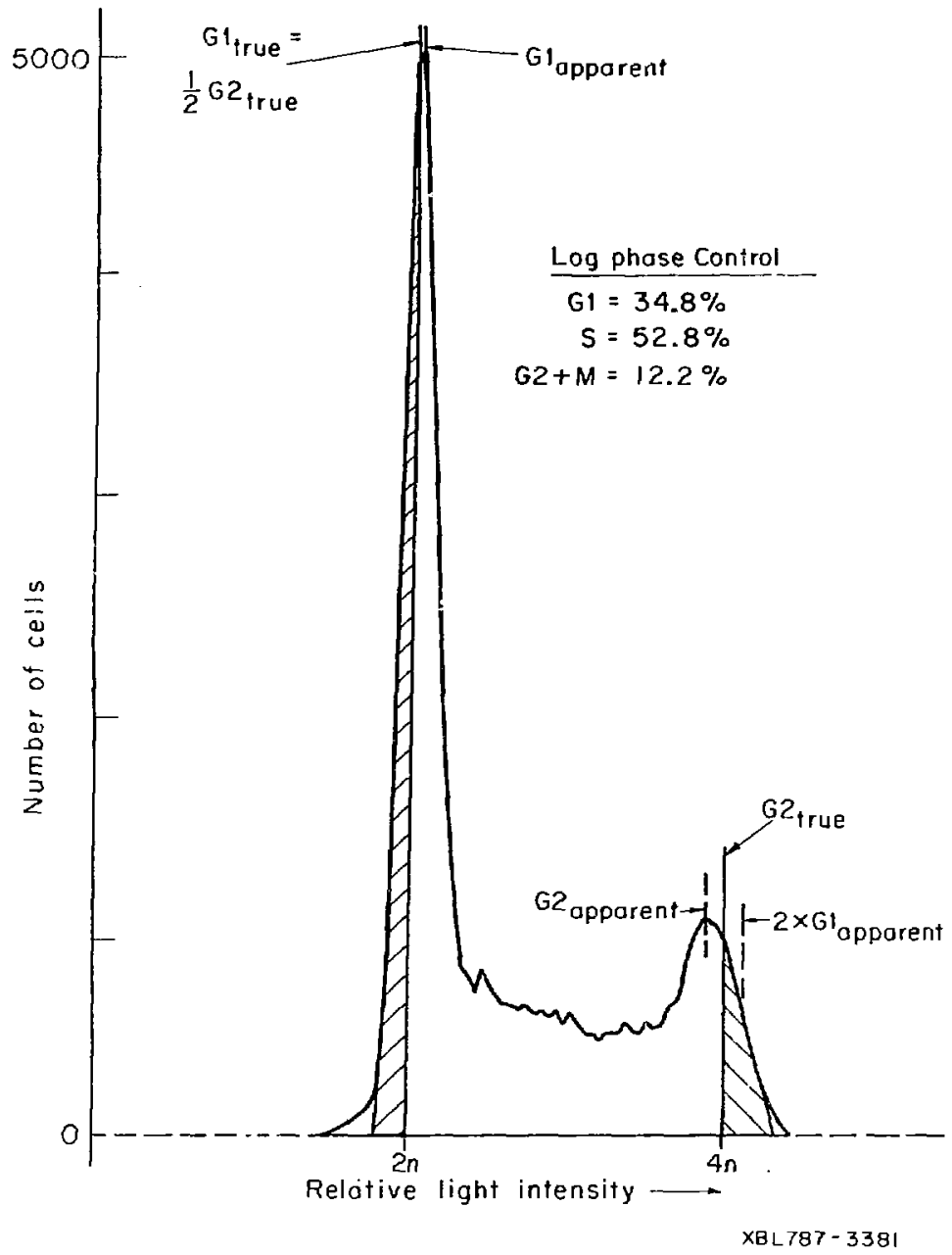

Fig. 1. Example of analysis of flow microfluorometry (FIF) togram. The area of the envelope representing the total celi population is measured with a planimeter. The subpopulation, Gl and G2.M are represented by twice the area of the appropriate right triangle. The $S$ population is represented by the remainder when $G 1$ and $G 2+M$ are subtracted frolu the total population. 


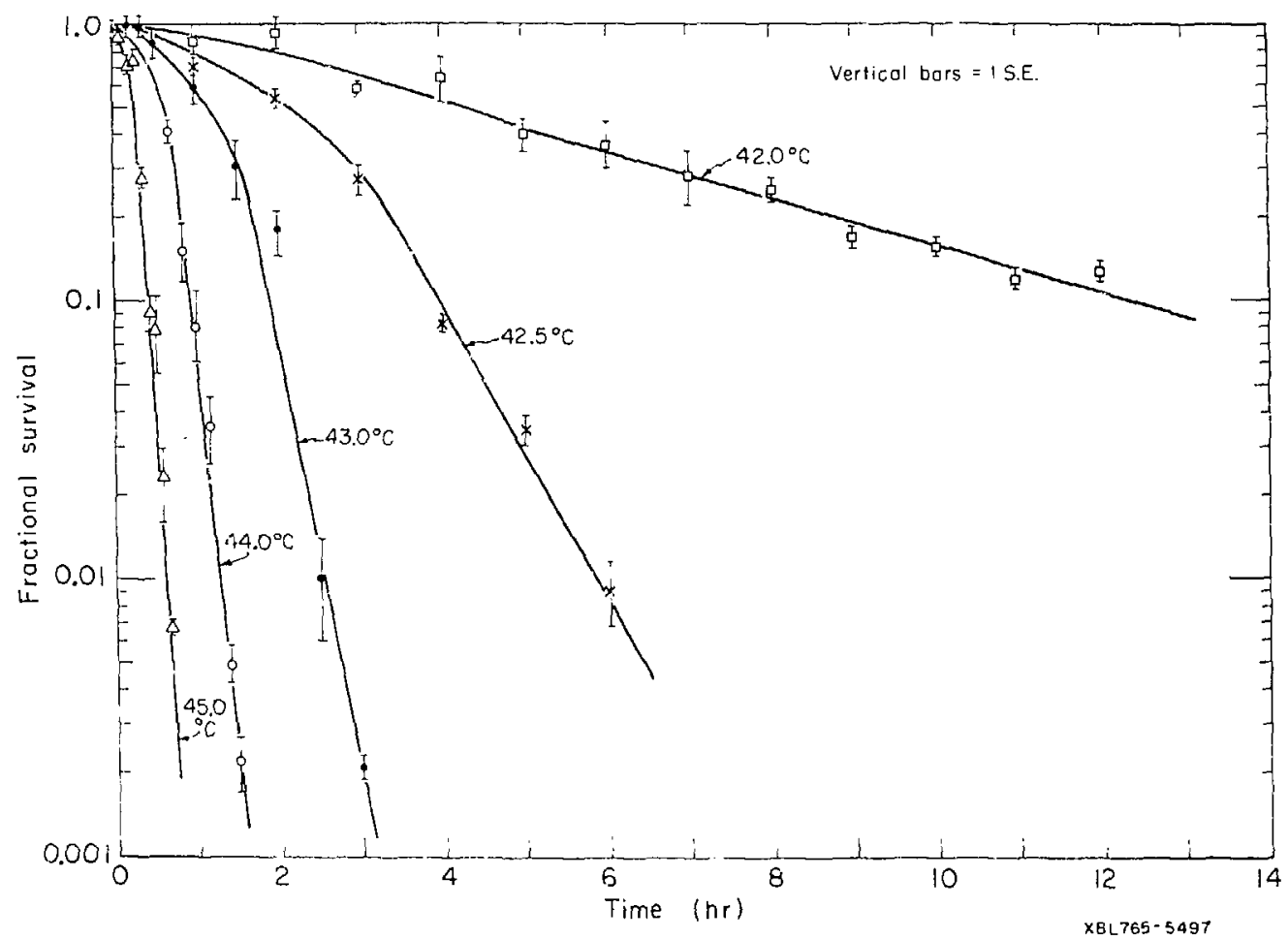

Fig. 2. Survival of asynchronous, exponentially growing 9L cells exposed fo different ter.ieratures for virying lengths of time. Exponential portions of curve are fitted by the method of least squares. Standard error of the control is propagated throupin normalization. 


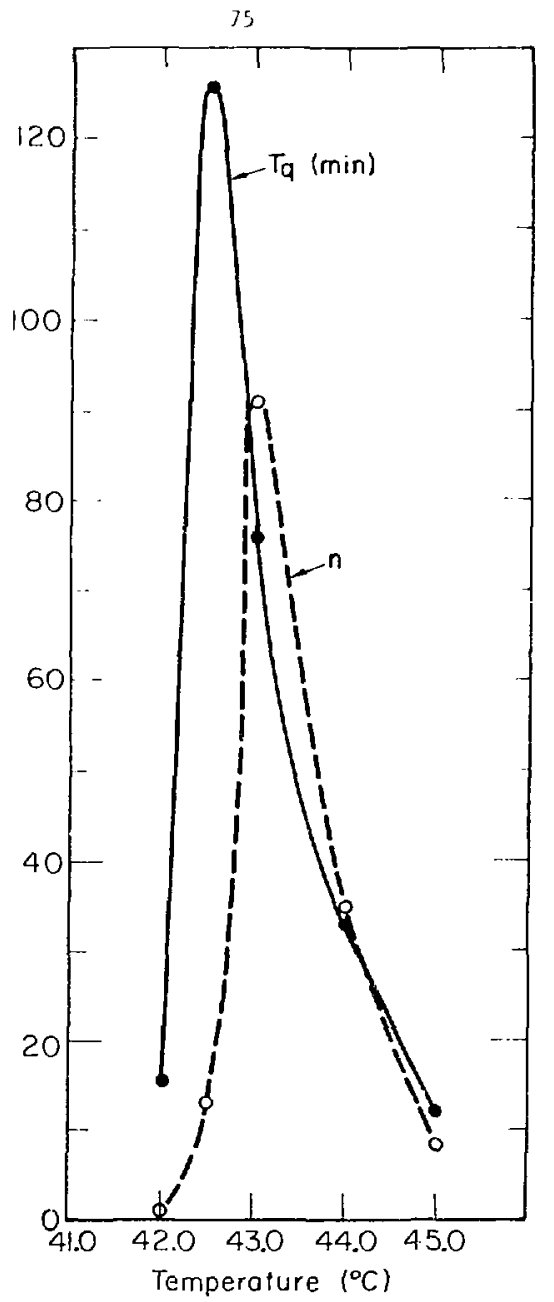

$x+7.75-3496$

Fig. 3. Variation of $T_{q}$ (Jin) and extrapoiation number " $n$ " with temperature showing discontinulty at $42.5^{\circ} \mathrm{C}$ and $43.0^{\circ} \mathrm{C}$, respectively. 


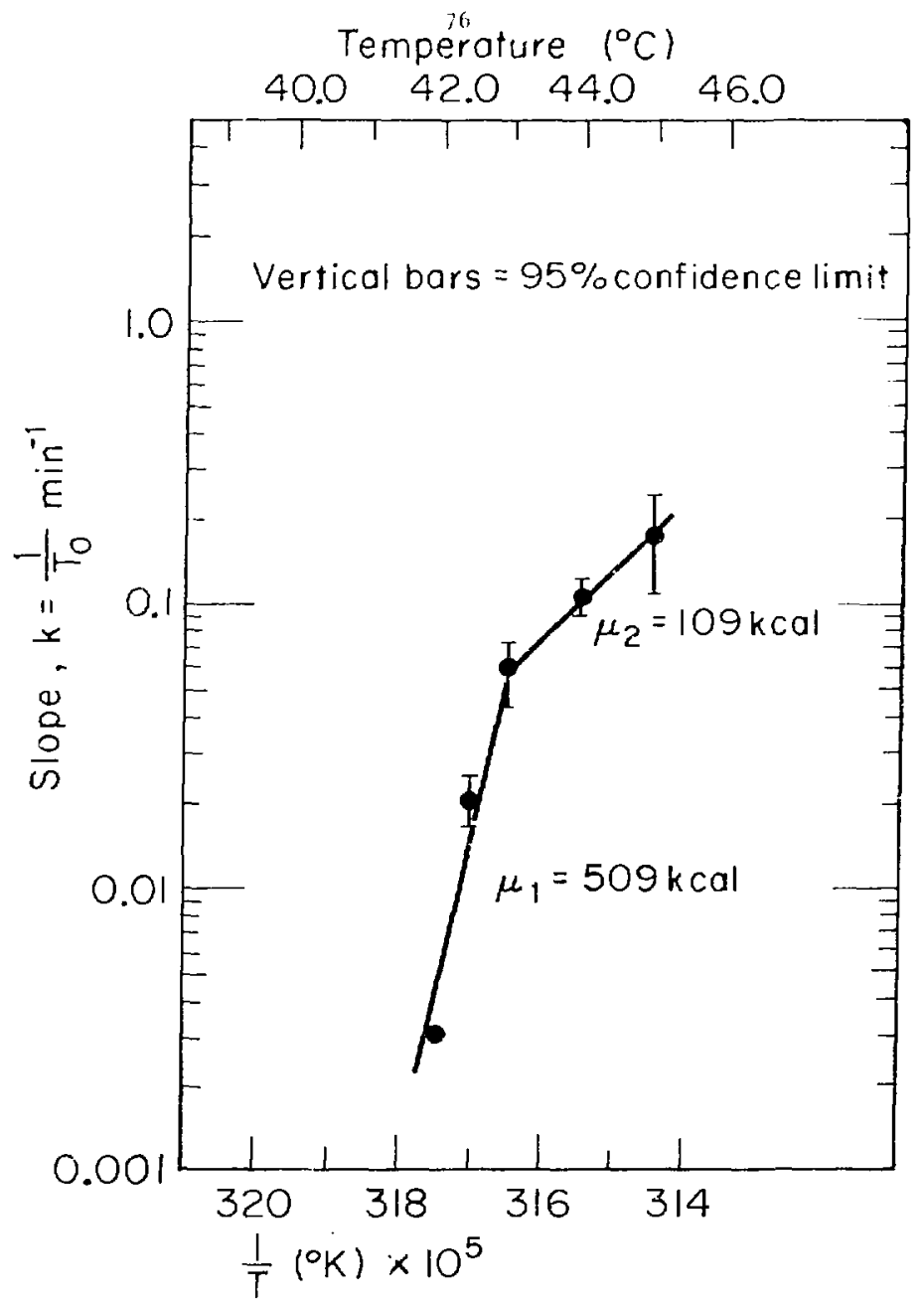

XBL787-3337

Fig. 4. Arrhenius analysts Variation of slope $\left(k=I / T_{0}\right)$ with temperature showing discontinuity at $43.0^{\circ} \mathrm{C}$. Confidence limit calculated from error in least squares determination of slope. 


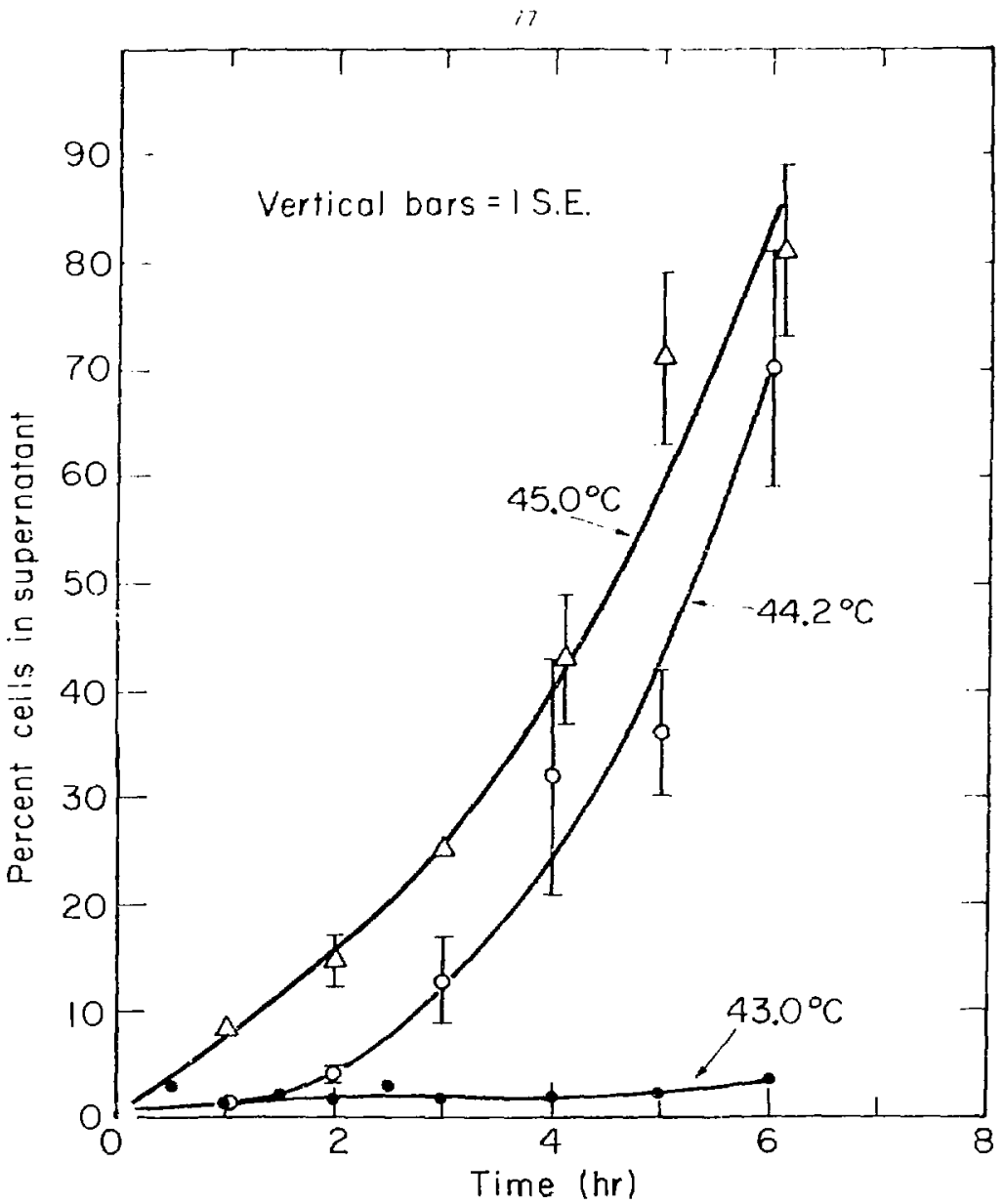

Xit.;iss-5, 01

Fig. 5. Percent cells in the supernatant as a function of tine at tempcrature. The percent cells in the supernatant = II supernatant celis $-\frac{\text { " supernatant }}{\text { \# attached cells }} \times 100$. Data is normalized to "he zero hour value. 

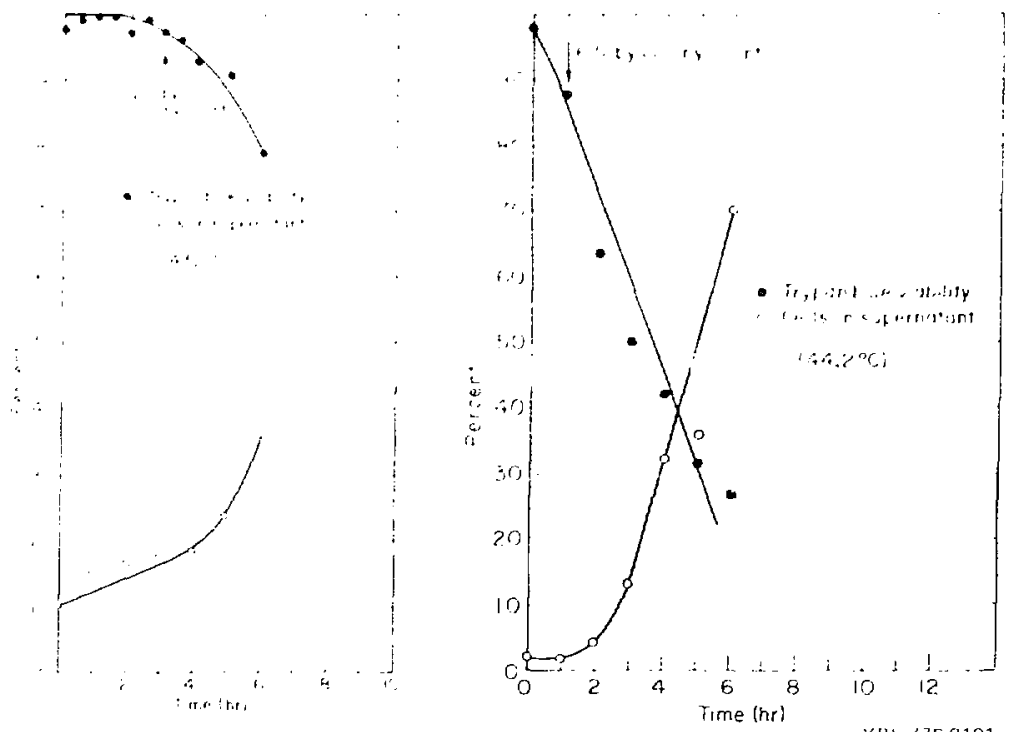

His. 6. Correlation between viability as nousured with Trylan Blue and rell detachment fros the growing surface of the flask, at $43.0^{\circ} \mathrm{C}$ and $44.2^{\circ} \mathrm{C}$, Percent cells in the supermatant =

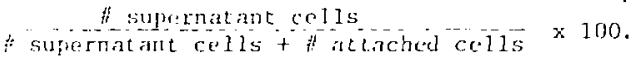




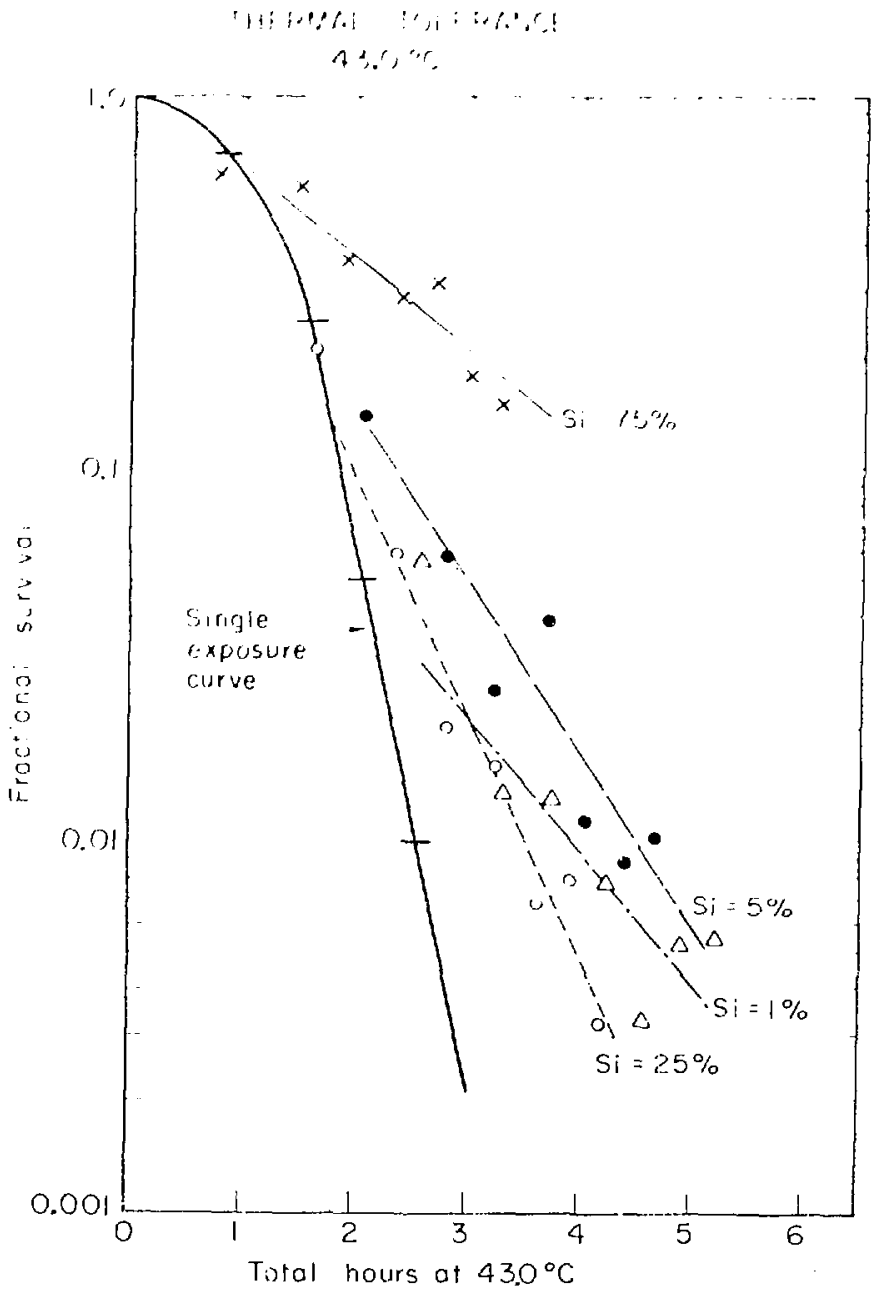

$\times B L 787-3344$

Fig. 7. Continuous curve repreients the cell survival response to single exposure to $43.0^{\circ} \mathrm{C}$. Other lines represent survival response when cells ware returned to $37.0^{\circ} \mathrm{C}$ for 3 hours before receiving a graded second exposure. The initial exposure was calibrated to redice survival to $75 \%(x)$, $50 \%(0), 5 \%(\bullet)$, or $1 \%(\Delta)$. 


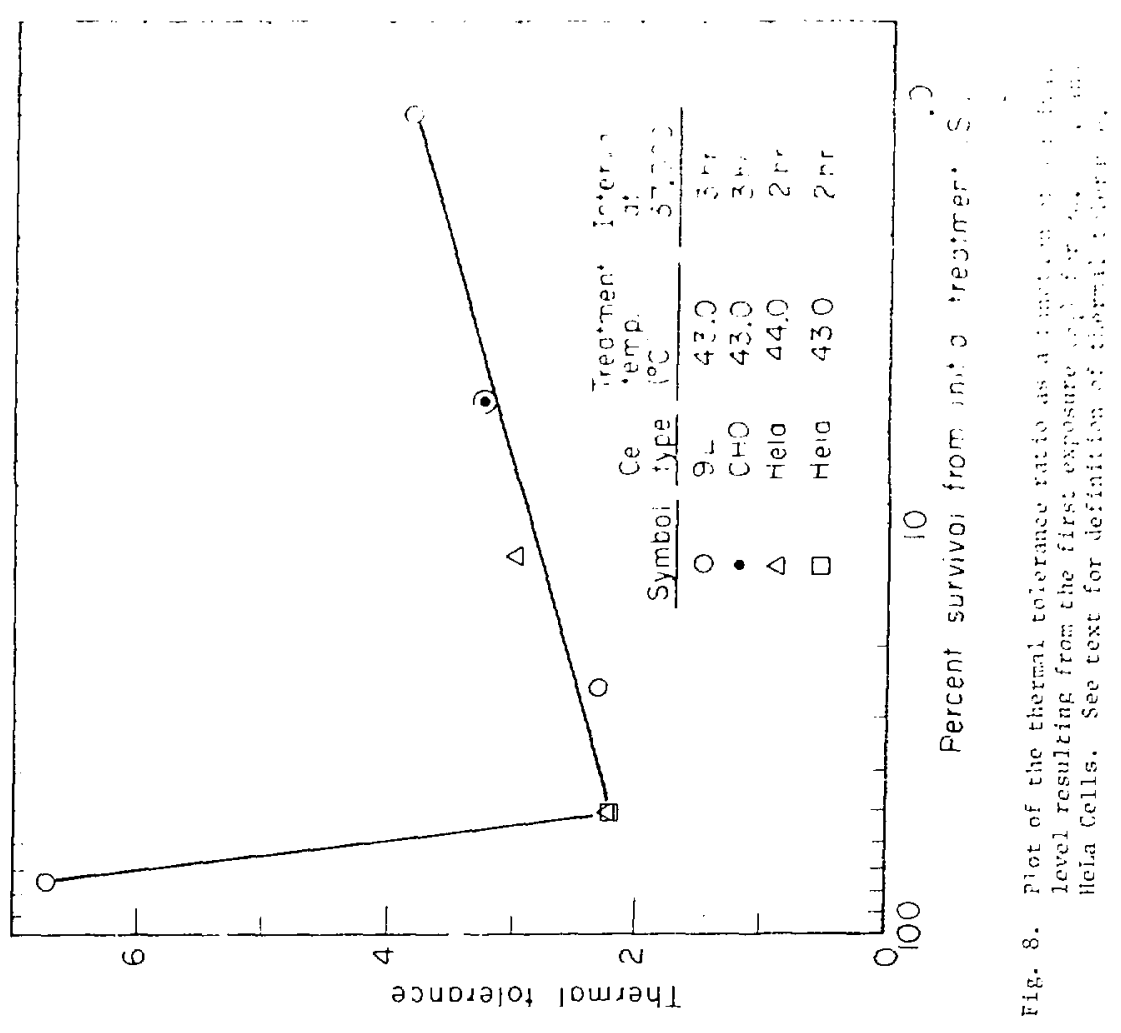




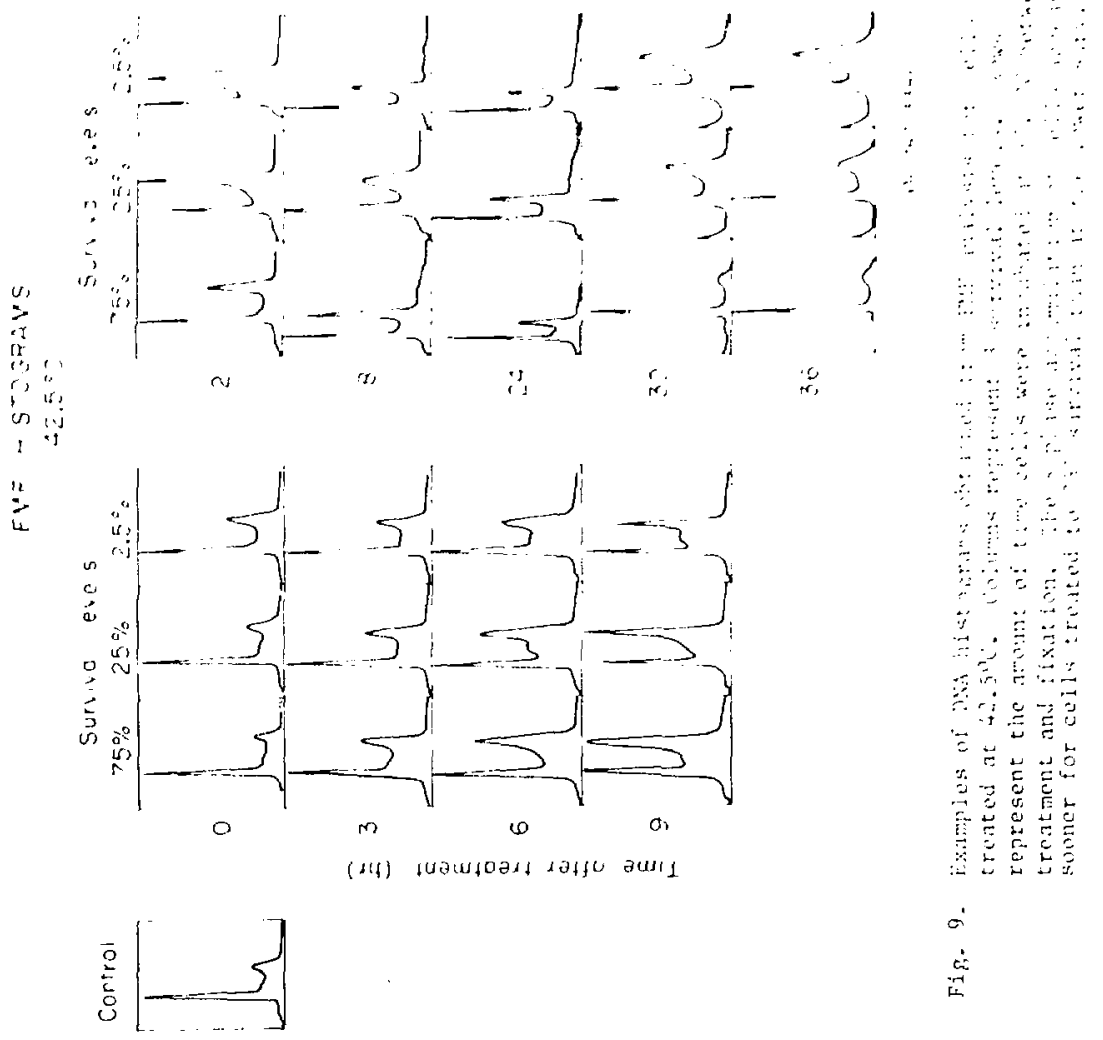




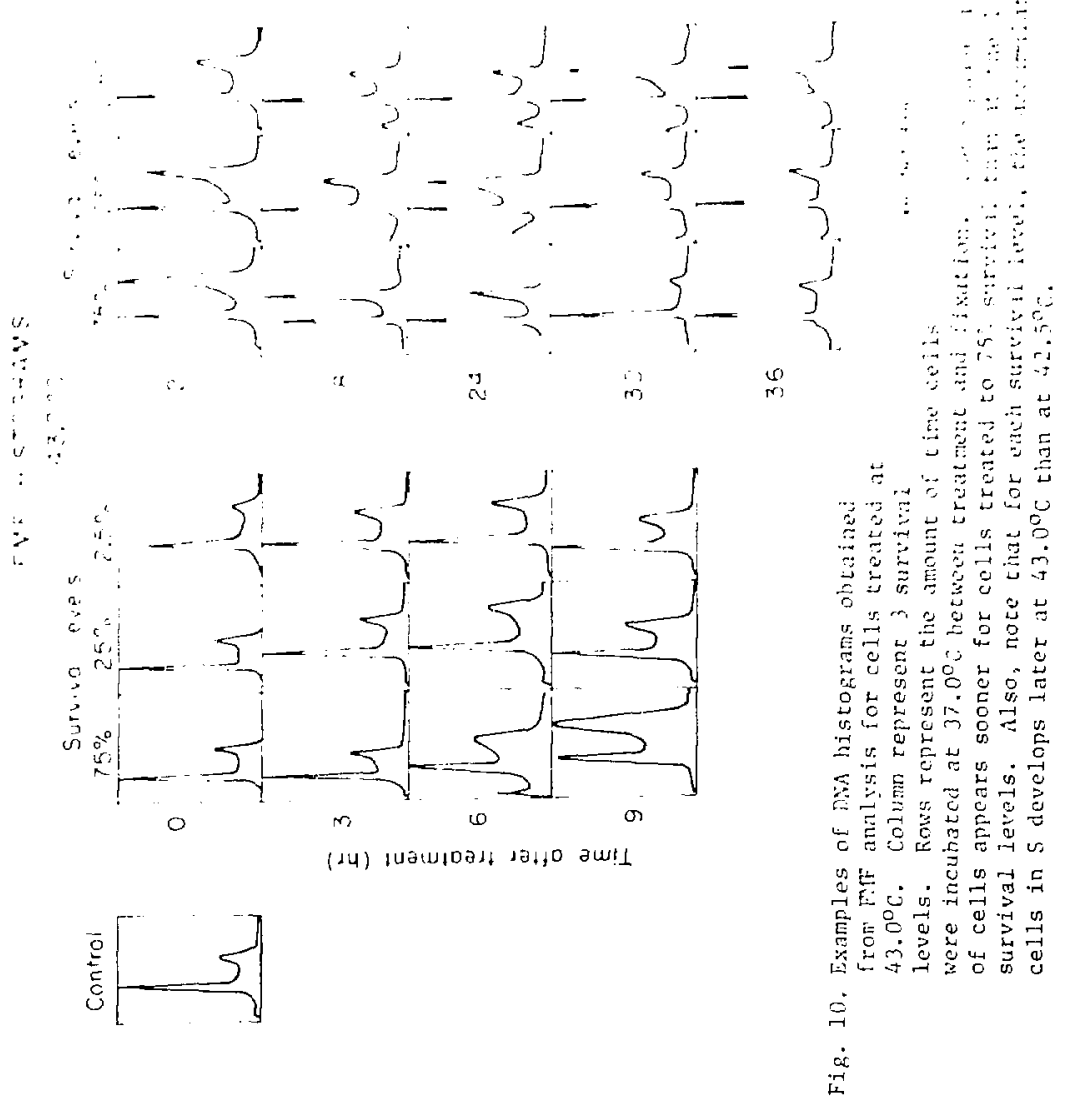




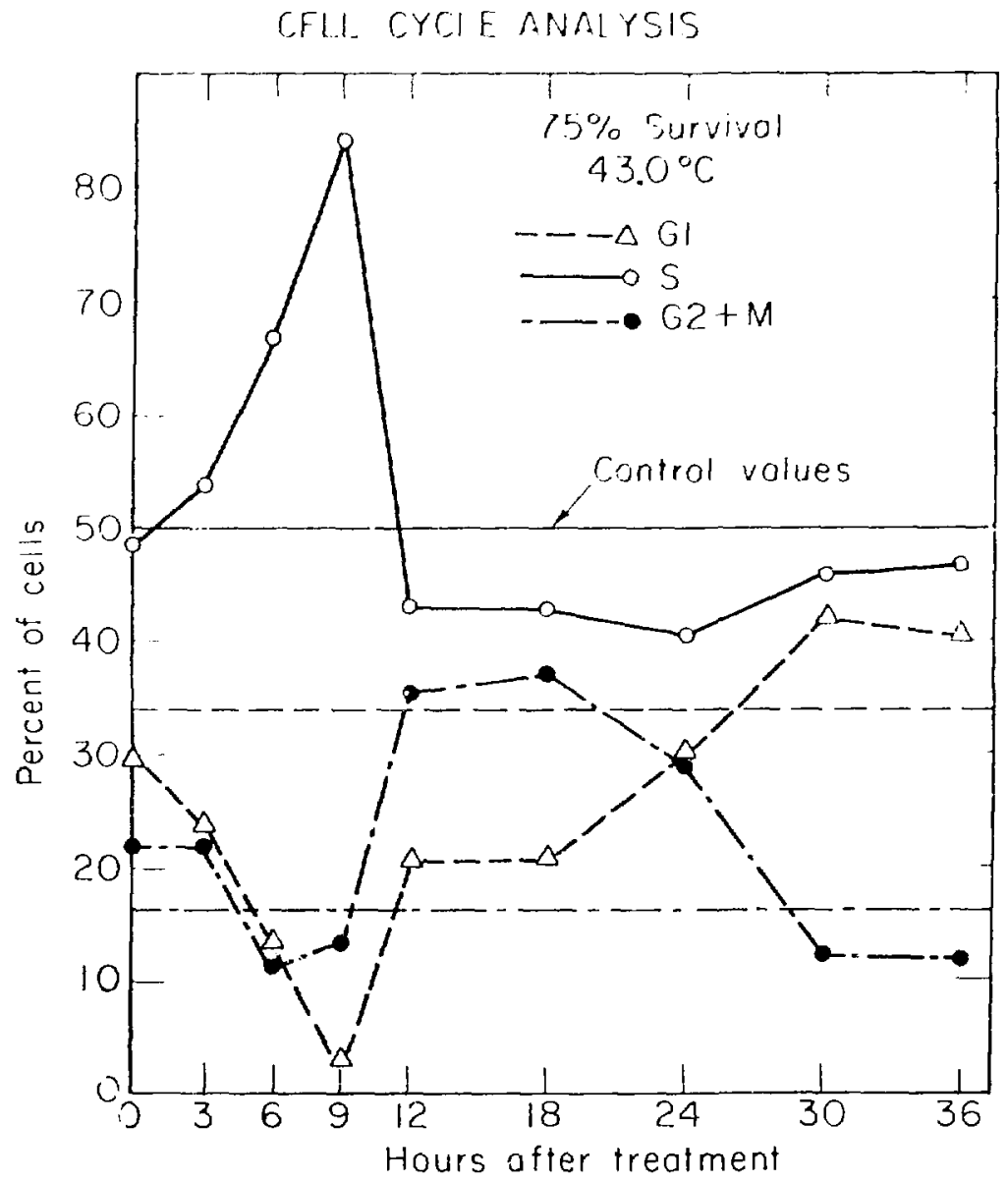

$\because 41.7711-31379$

Fis. 11. Ciraphical rosult of planimeter analyeis of cells treated to $75 \%$ survival at $43.0^{\circ} \mathrm{C}$. The rohort of cress accumulated in

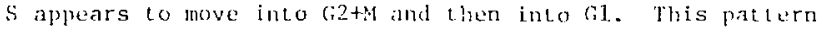
was also ohserved for al other temperatures and survival levels st ulliod. 


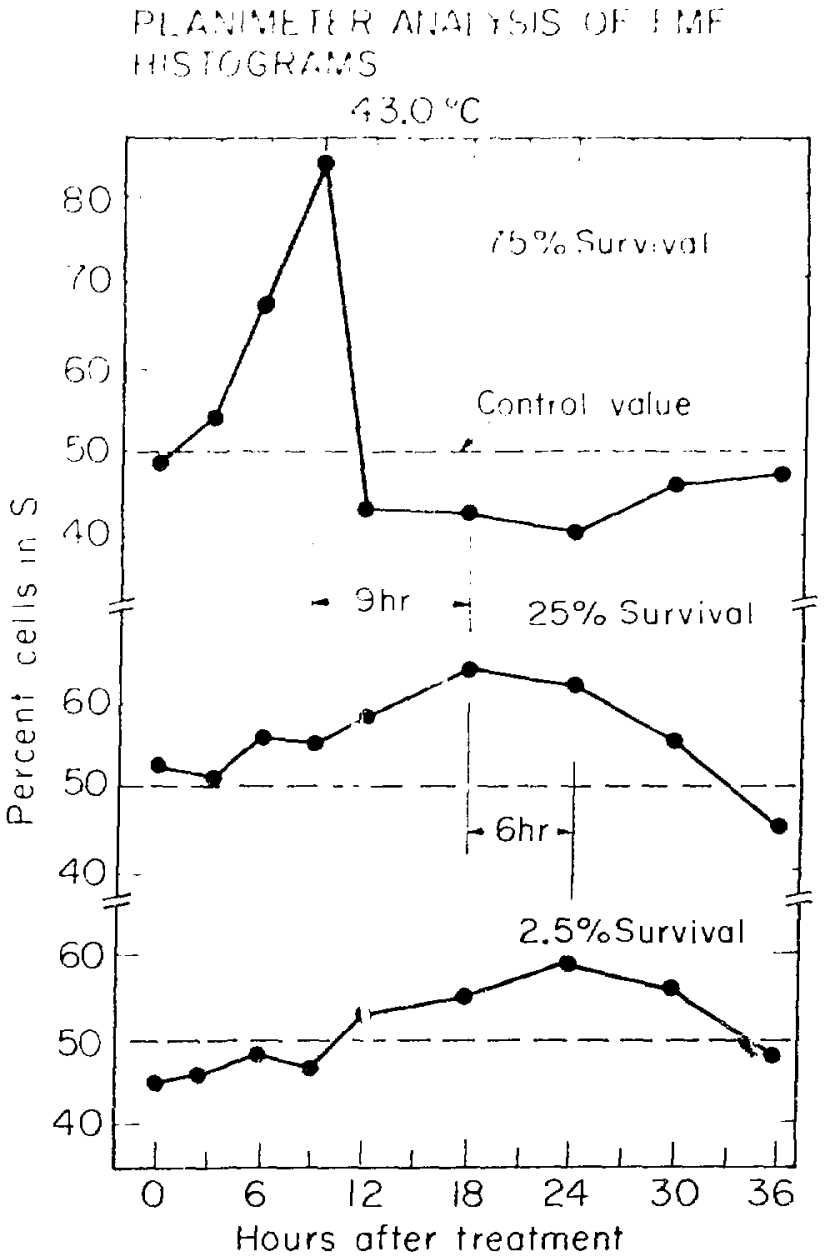

$\therefore 1.767-3339$

Fig. 12. Comprarison of the time it lakes colls to accumulate in $S$ chepriding on the survival luvel to which thoy are truated using $43.0^{\circ} \mathrm{C}$. Notice that lergth of frcneral artest increnses with decrcasing survival. 


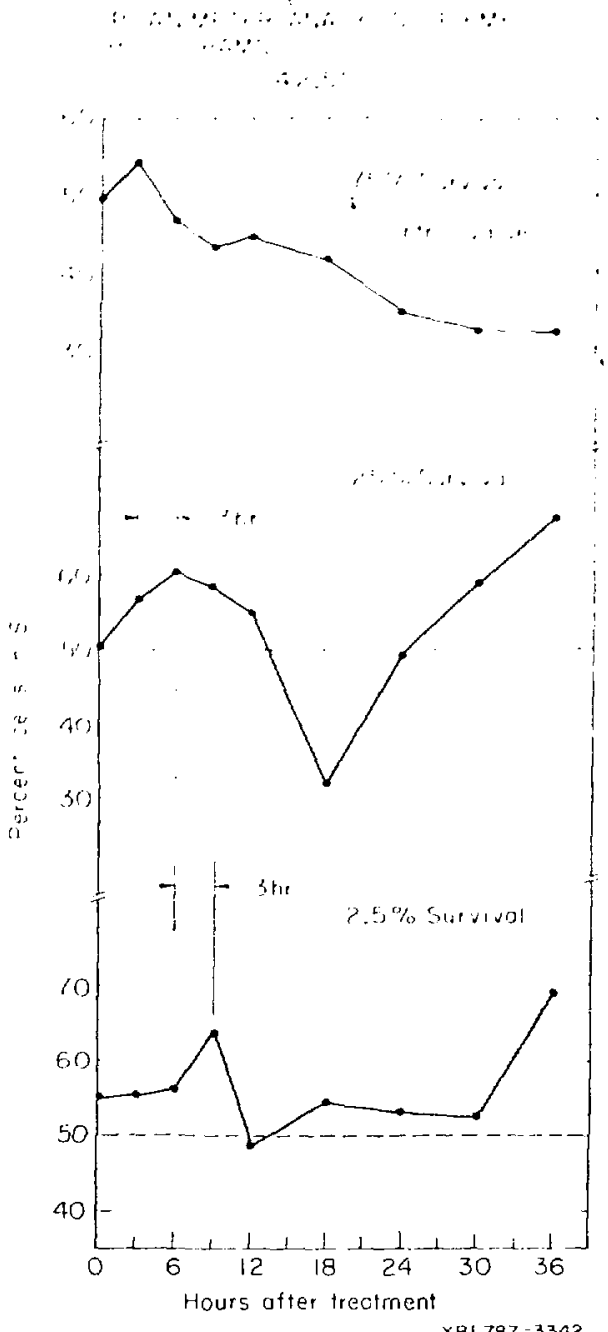

Fig. 13. Comparison of the tine it takes cells to accumilate in $S$ depending on the survival Jevel to which tye are treated using $42.5^{\circ} \mathrm{C}$. Notice that length of general arrest increases with decreasing survival. 


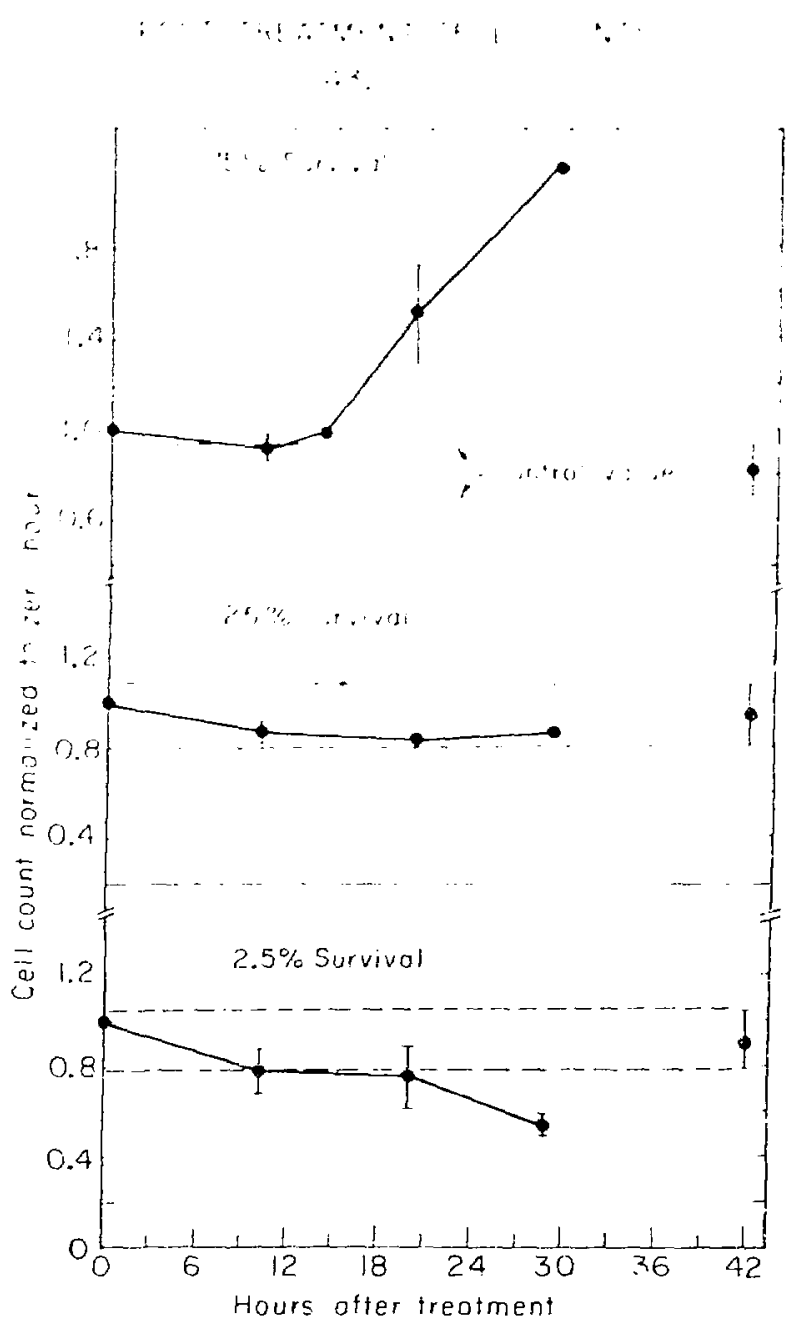

XBI. $787-3345$

Fig. 14. kate of diacease in ceil population with time at $37.0^{\circ} \mathrm{C}$ after treatment at $43.0^{\circ} \mathrm{C}$ Lo $75 \%, 25 \%$, and $2.5 \%$ sirvival levels. Aotice tet lemplh of frowth delay inereases with decreasing survival. 
POST TREATMENT CELL COUNTS

$42.5^{\circ} \mathrm{C}$

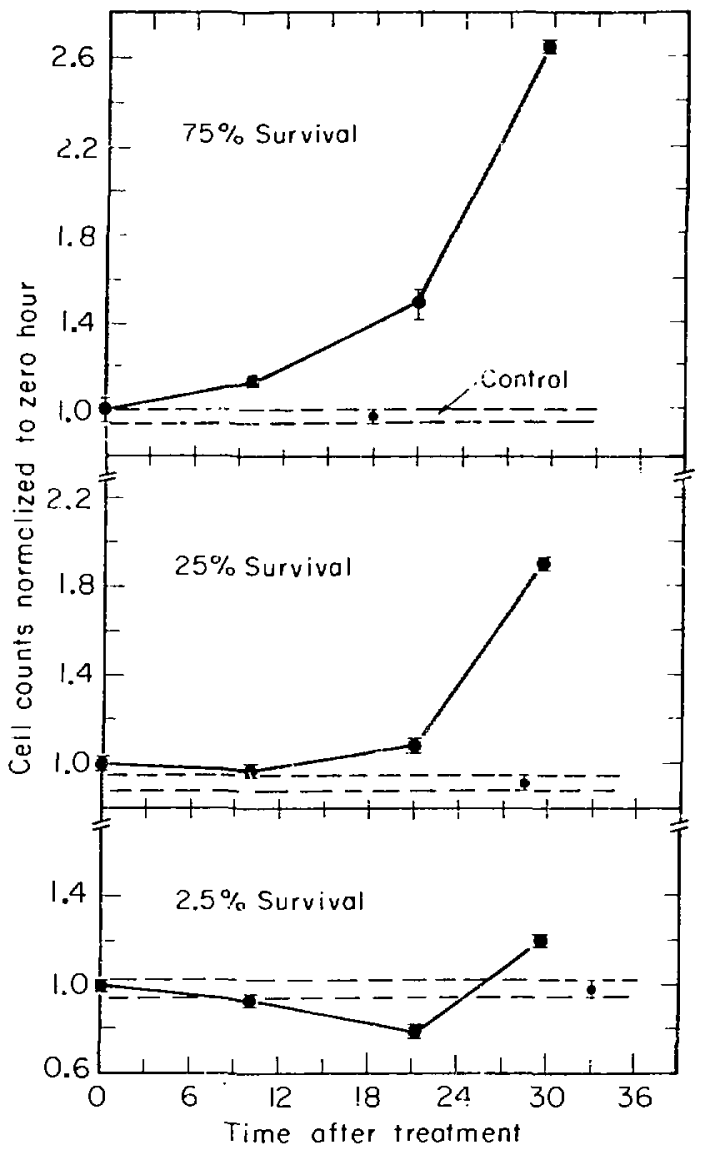

XBL $787-3380$

Fig. 15. Rate of increase in cell population with time at $37.0^{\circ} \mathrm{C}$ after treatment at $42.5^{\circ} \mathrm{C}$ to $75 \%, 25 \%$, and $2.5 \%$ survival levels. Notice that length of growth delay increases with decreasing survival. 
PLANIMETER ANALYSIS OF FMF HISTOGRAMS

$75 \%$ Survival

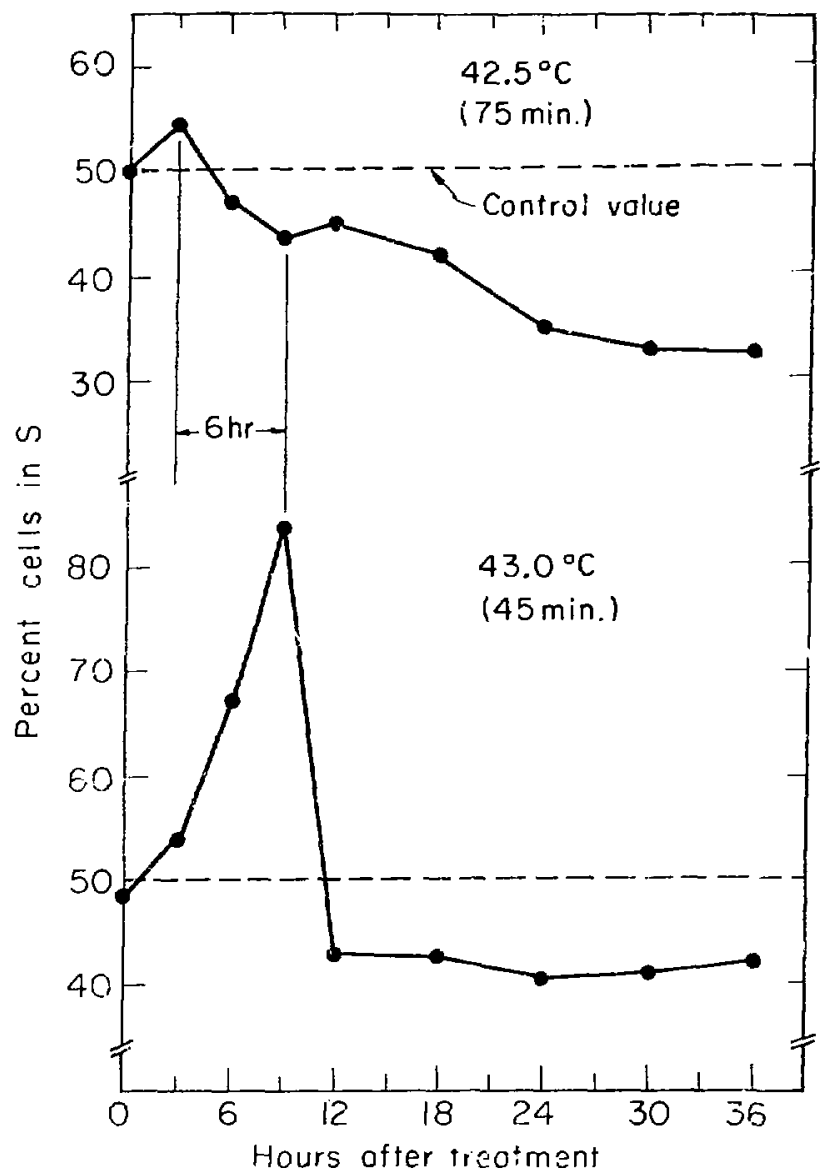

SHL $787-3341$

Fig. 16. Comparison of time it takes cells to accumatate in $S$ for iso-survival of $75 \%$ achieved by testing for either $75 \mathrm{~min}$ at $42.5^{\circ} \mathrm{C}$ or $45 \mathrm{~min}$ at $43.0^{\circ} \mathrm{C}$. 
89

PLANIMETER ANALYSIS OF FMF HISTOGRAMS

\section{$25 \%$ Survival}

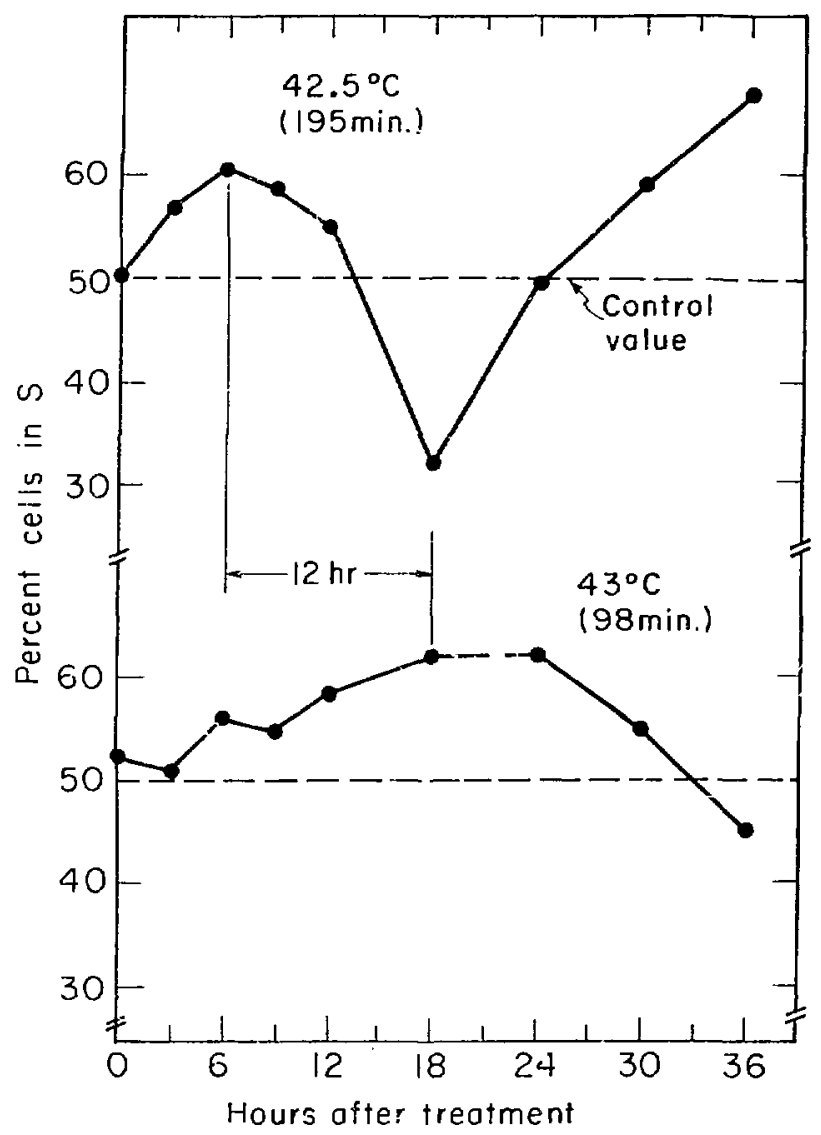

YisL.787-3338

Fig. 17. Comparison of time it takes cells to accumulate in $S$ for ios-survival of $25 \%$ achieved either by treating at $42.5^{\circ} \mathrm{C}$ for $195 \mathrm{~min}$ or at $43.0^{\circ} \mathrm{C}$, or $98 \mathrm{~min}$. 
PLANIMETER ANALYSIS OF FMF HISTOGRAMS

$2.5 \%$ Survival

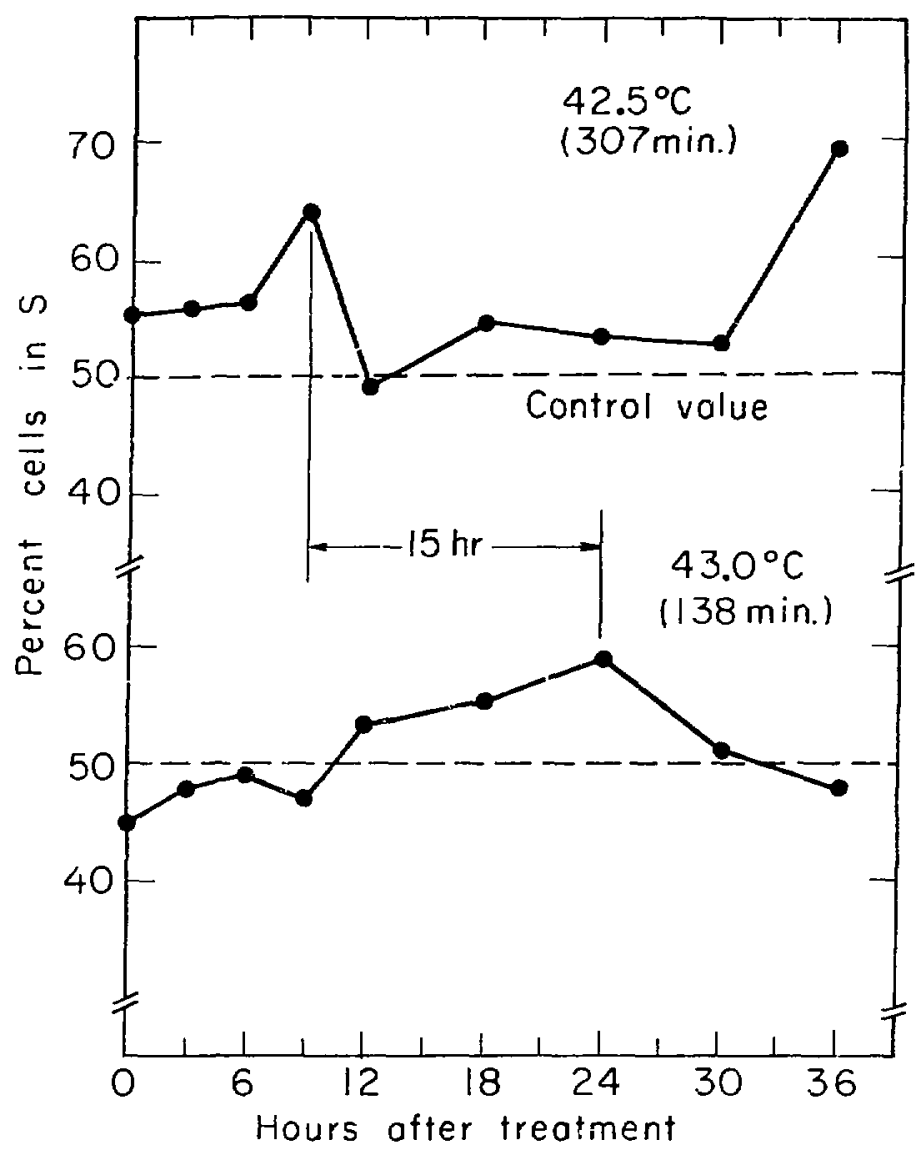

XHL787-3340

Fig. 18. Comparison of time it takes cells to accundate in $S$ for iso-survival of $2.5 \%$ achieved either by treating at $42.5^{\circ} \mathrm{C}$ for $307 \mathrm{~min}$ or at $43.0^{\circ} \mathrm{C}$ at $138 \mathrm{~min}$. 
PLANIMETER ANALYSIS OF FMF

HISTOGRAMS USING FOUR TEMPERATURES $25 \%$ Surviving

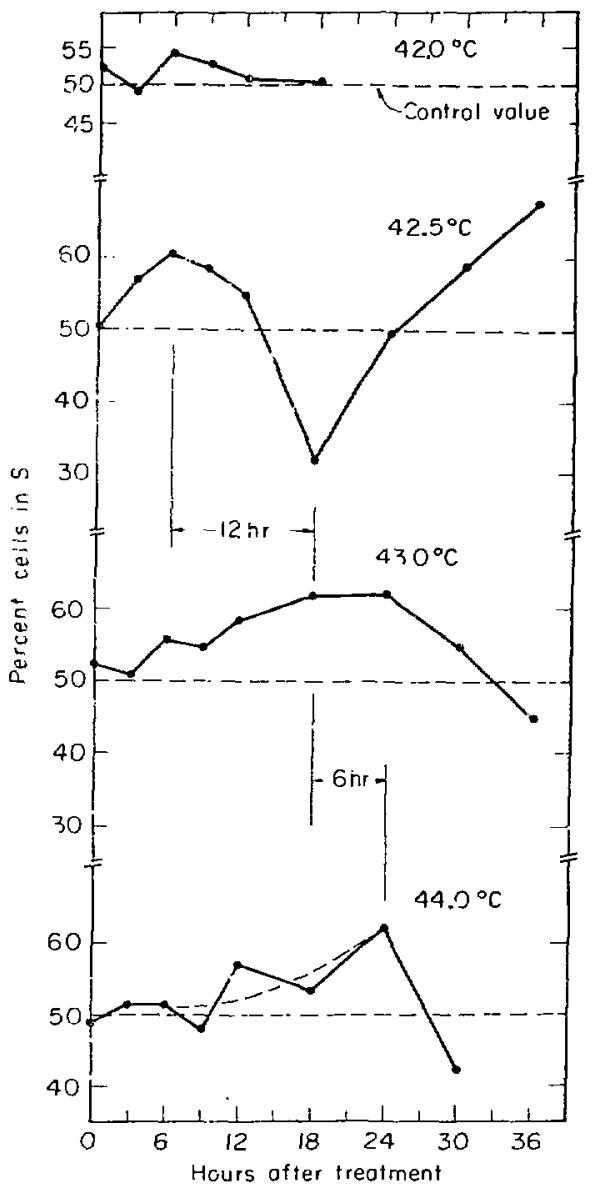

$\times B L 787-3343$

Fig. 19. Illustration of the general trend that the length of the general arrest increase; with increasing temperature for iso-survival. 


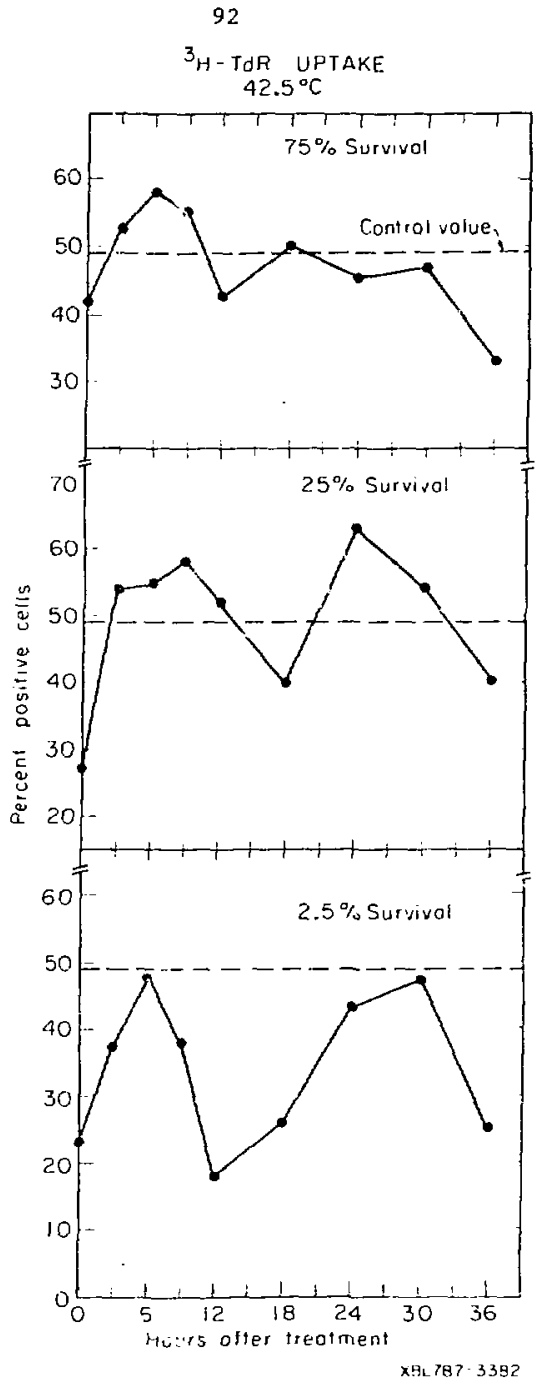

Fig. 20. Labelled population as a function of time at $37.0^{\circ} \mathrm{C}$ after treating cells at $42.5^{\circ} \mathrm{C}$ to survival 1 evels of $75 \%, 25 \%$, and $2.5 \%$. 


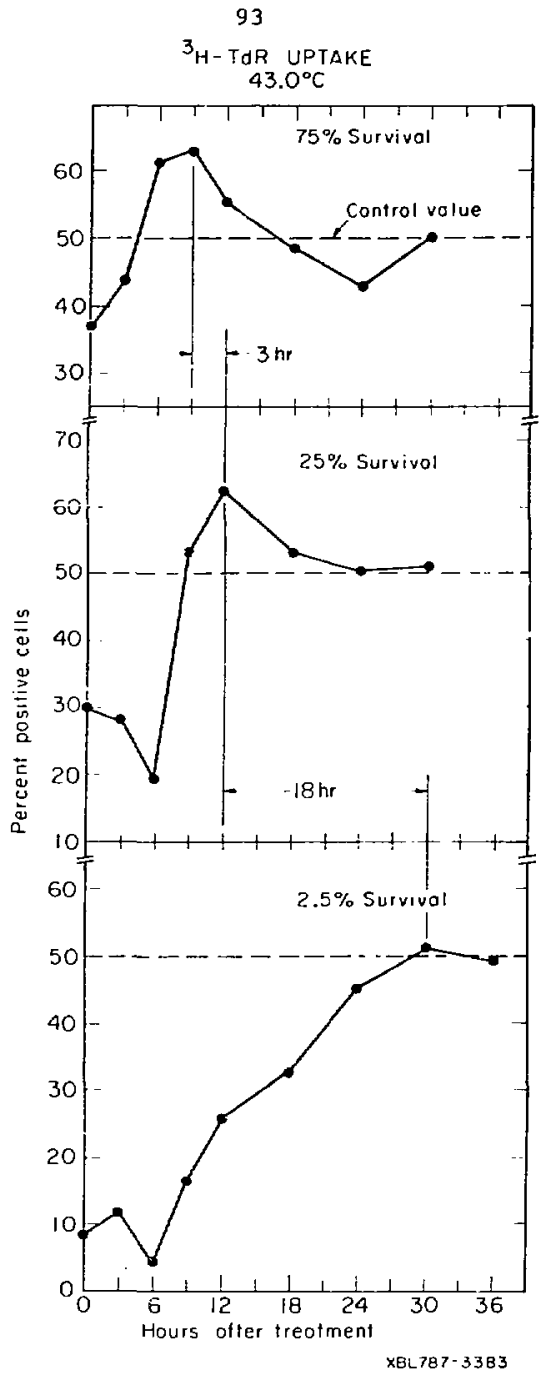

Fig. 21. Labelled population as a function of time at $37.0^{\circ} \mathrm{C}$ after treating cells at $43.0^{\circ} \mathrm{C}$ to survival lavels of $75 \%, 25 \%$, and $2.5 \%$. The lengtin of the general arrest increases with decreasing survival. 


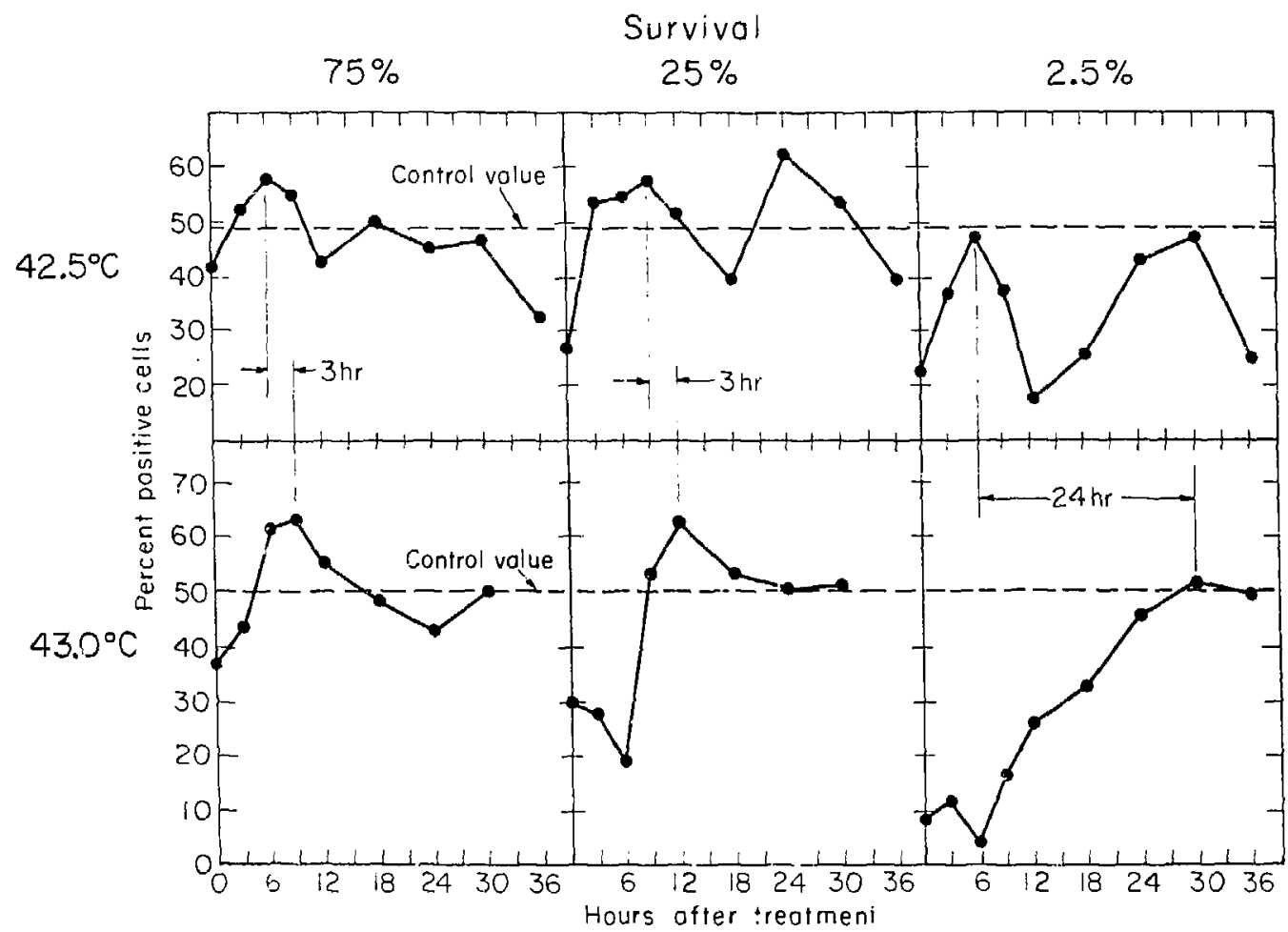



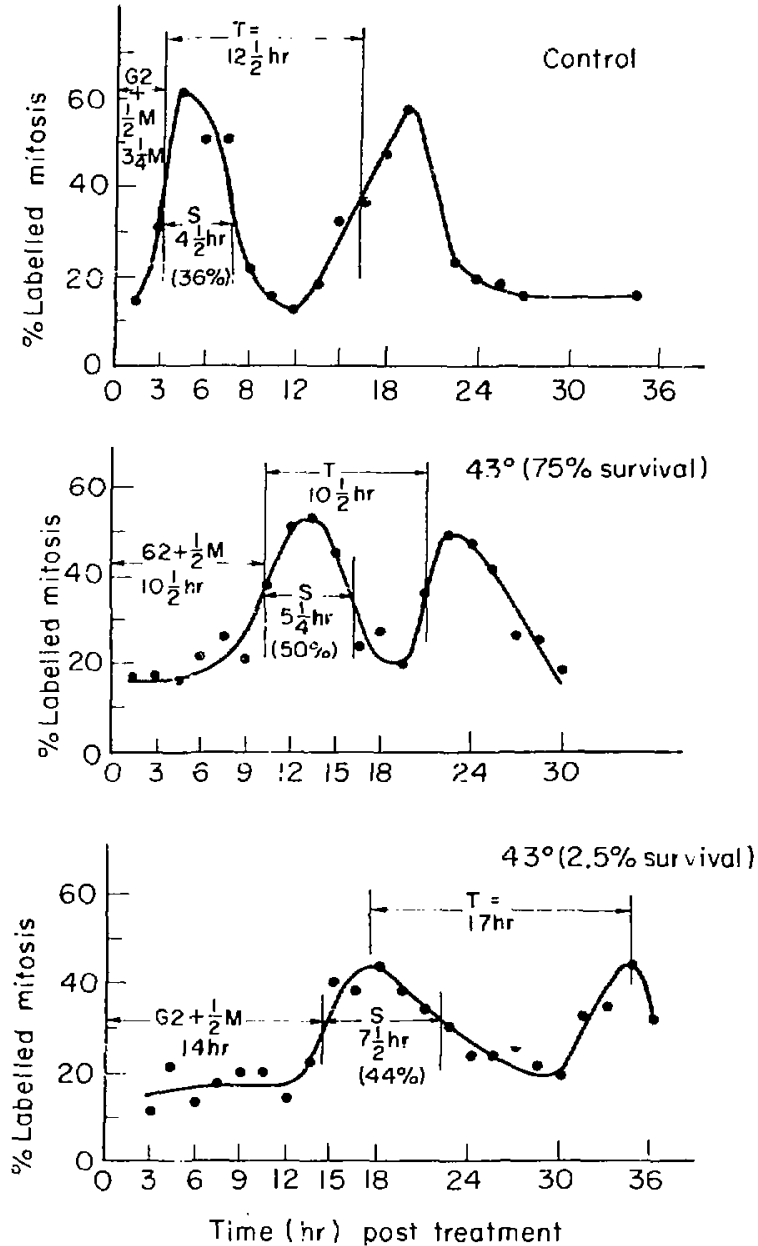

XBL787-3379

Fig. 23. Fulse labelled mitoses curves for control cells and celis treated at $43.0^{\circ} \mathrm{C}$ to $75 \%$ survival and $2.5 \%$ survival. The progressive increase in the initial G2+ll phase corresponds to pattern in which the general arrest increases. 


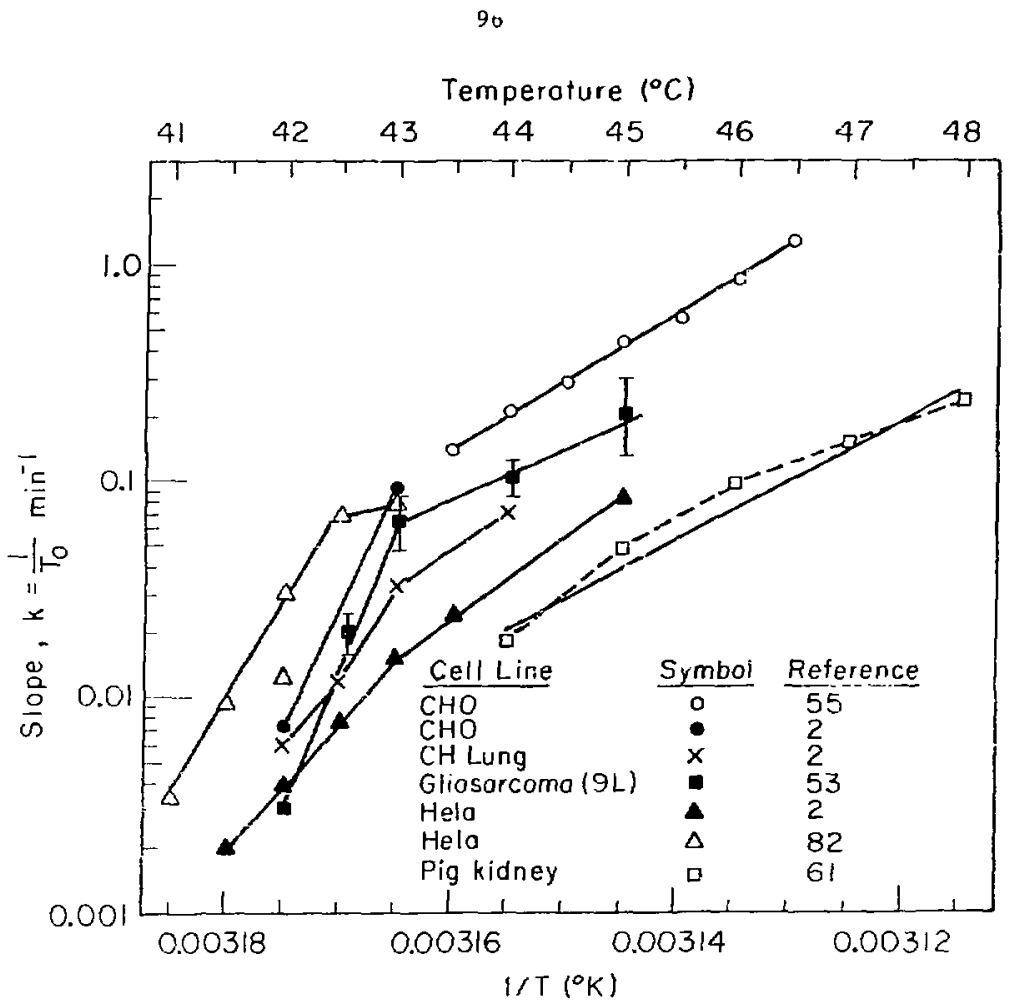

XBL $786-3253$

Fig. 24. Arrhenius plot for cell inactivation of several cell lines. Approximateíy parallel slopes may inficate similar inactivation mechanisms for many cell lines. 